\title{
Phytochemical composition and bioactivities of hawthorn (Crataegus spp.): review of recent research advances
}

\begin{abstract}
Petras Rimantas Venskutonis*
Department of Food Science and Technology, Kaunas University of Technology, Radvilènų rd. 19, Kaunas, LT-50254, Lithuania

${ }^{*}$ Corresponding author: Petras Rimantas Venskutonis, Department of Food Science and Technology, Kaunas University of Technology, Radvilènų rd. 19, Kaunas, LT-50254, Lithuania. E-mail: rimas.venskutonis@ktu.lt

DOI: $10.31665 /$ JFB.2018.4163

Received: December 04, 2018; Revised received \& accepted: December 23, 2018

Abbreviations: ABTS, 2,2'-azino-bis(3-ethylbenzothiazoline-6-sulphonic acid; AChE, acethylcholinesterase; AMP, adenosine monophosphate; BchE, butyrylcholinesterase; CPT-1, carnitine palmitoyl transferase; DPPH', stable 2,2-diphenyl-1-picrylhydrazyl radical; DW, dry weight; eNOS, endothelial NO synthase; FRAP, ferric reducing antioxidant power; GAE, gallic acid equivalents; Gpx3, glutathione peroxidase 3; HDLC, high density lipoprotein cholesterol; HFD, high-fat diet; HLF, hawthorn leaf flavonoids; ICAM-1, intercellular adhesion molecule; IL, interleukin; LDLC, low density lipoprotein cholesterols; LPS, lipopolysaccharide; MDA, malondialdehyde; NAFLD, nonalcoholic fatty liver disease; NO, nitric oxide; ORAC, oxygen radical absorbance capacity; PKC- $\alpha$, protein kinase C $\alpha$; PPAR $\alpha$, peroxisome proliferator activated receptor $\alpha$; RAW264.7, murine macrophage cell line; RCT, reverse cholesterol transport; ROS, reactive oxygen species; SOD, superoxide dismutase; SREBP-1c, sterol regulatory element binding protein-1c; TBARS, thiobarbituric acid reactive substances; TC, total cholesterol; TE, trolox equivalents; TFC, total flavonoid content; TG, triacylglycerols; TNF- $\alpha$, necrosis factor- $\alpha$; TPC, total phenolic content; VLDLC, very low density lipoprotein cholesterol.
\end{abstract}

Citation: Venskutonis, P.R. (2018). Phytochemical composition and bioactivities of hawthorn (Crataegus spp.): review of recent research advances. J. Food Bioact. 4: 69-87.

\begin{abstract}
Hawthorn (Crataegus spp.) is one of the most famous plants which has been used as natural medicine and nutraceutical. Its phytochemical composition, bioactive compounds and health benefits have been intensively studied and hawthorn preparations may be recognized as classical natural products for cardiovascular health. Polyphenolic compounds of different hawthorn anatomical parts as well as their extracts have been the focus of a majority of these studies, although various other classes of natural health promoting constituents have also been isolated, identified and characterized. Regardless, numerous published reports have particularly focused on the activity mechanisms which are very important for supporting various health benefits. This review summarizes the most recent studies on hawthorn, mainly published since 2015. Search of different databases indicates that approximately 200 publications, which are relevant to phytochemistry and health benefits of Crataegus spp., have appeared since then, most of them have not been included in the existing reviews.
\end{abstract}

Keywords: Hawthorn (Crataegus spp.); Phytochemical composition; Bioactivities; Health benefits; Toxicity.

\section{Introduction}

Hawthorns are large genus of small shrubs and trees belonging to Rosaceae family, Amygdaloideae subfamily, Maleae tribe, Malinae subtribe Crataegus Tourn. ex L. genus. Nowadays it is agreed that the genus is represented by approximately 200 spe- cies which are native to temperate regions of the Northern Hemisphere in North America, Europe and Asia (Phipps et al., 2003). The name "hawthorn" is often used in some countries although originally it was applied to the species native to northern Europe, especially to the common hawthorn (C. monogyna). Red or black small pome fruits of some Crataegus spp. are edible, e.g. fresh fruits of $C$. orientalis, while the fruits of other species 
become eatable in late autumn. Their flavor has been compared to over-ripe apples and they are mainly used for jellies or homemade wine. Picked in spring young leaves are also edible and are tender enough to be used in salads. In Europe, the fruit, leaves, and flowers were traditionally employed for treating heart problems due to their antispasmodic, cardiotonic, hypotensive, and antiatherosclerotic effects. Nowadays, hawthorn preparations are mainly used as cardioprotective agents (Fong and Bauman, 2002); however, in traditional medicine it remains as a therapeutic agent for many other diseases including cancer, diabetes, cough, flu, asthma, stomach ache, rheumatic pain, nephritis, and hemorrhoids.

Among plant species $C$. pinnatifida (ten varieties of Chinese hawthorns) have long been used in traditional Chinese and European herbal medicines, and are widely consumed in the form of juice, drink, jam and canned fruit, while C. monogyna is commonly cultivated in the Mediterranean countries (Çalişkan, 2015). Chinese hawthorns comprise 18 species, however currently only C. pinnatifida and C. pinnatifida var. major fruits are included in the Chinese Pharmacopoeia. C. pinnatifida and C. scabrifolia fruits have also been traditionally used as peptic agents in oriental medicine and recently in a various local sweet foods, mainly soft drinks, jams, juices, tinned foods, and wines (Jurikova et al., 2012).

Several reviews summarizing numerous research findings on hawthorns are given in Table 1. Composition and health effects of phenolic compounds in Crataegus spp. of different origins was reviewed by Yang and Liu (2012), while Edwards et al. (2012) focused their review on the chemistry of the genus. Effects of bioactive natural products of Crataegus spp. on the vascular endothelium were also reviewed (Ahmad et al., 2013). More recently, polyphenolic composition and medical applications of C. monogyna were reviewed (Nabavi et al., 2015) by summarizing the growing evidence on various interesting physiological and pharmacological activities of this species due to the presence of different bioactive natural compounds. Nunes et al. (2017) reviewed the labeling and safety concerns of herbal products containing Crataegus spp. among other ingredients. Rastogi et al. (2016) provided a review on the cardiovascular effects of $C$. oxyacantha, including ischemic heart disease, congestive heart failure, arrhythmias and hypertension and concluded that, although the mechanisms of action are not very clear, there is enough evidence of their efficacy in various cardiovascular disorders.

C. oxyacantha is a widely used Chinese herb for treating gastrointestinal ailments and heart problems; it is also consumed as a food. In North America, the role of treating heart problems dates back to the 1800 's. Currently, the evidence is accumulating from various in vivo and in vitro studies that hawthorn extracts exert a wide range of cardiovascular and pharmacological properties, including antioxidant activity, positive inotropic, antiinflammatory, anticardiac remodeling, antiplatelet aggregation, vasodilating, and endothelial protective effects, as well as reduction of smooth muscle cell migration and proliferation, protection against ischemia/reperfusion injury, antiarrhythmic, lipidlowering and arterial blood pressure decreasing effects (Wang et al., 2013).

Crataegus spp. were also reviewed together with other botanicals (Chen et al., 2009; Schmitt and Dirsch, 2009; Rastogi et al., 2016; Dennehy, 2001; Bjorklund et al., 2018), Chinese Traditional Medicine plants (Xie et al., 2012; Liu and Huang, 2016; Dong et al., 2017), various herbal products (Ahmad et al., 2013; Nunes et al., 2017), nutraceuticals (Houston, 2005) and natural antioxidants (Zhao, 2005).

\section{Bioactive constituents and antioxidant/antiinflammatory ac-} tivities

The variations in the composition of different Crataegus spp. from various growing regions, as well as of different anatomical parts of hawthorn have been widely studied. Acids, sugars and sugar alcohols, minerals, vitamins, and amino acid composition were among the analyzed constituents, however, overwhelming number of published articles have been focusing on polyphenolic compounds, as the most important hawthorn bioactive phytochemicals which may provide health benefits to humans. Consequently, many hawthornbased preparations are standardized according to the content of their flavonoids and phenolic acids. The interest in phenolic and polyphenolic compounds particularly increased in the era of functional foods (Shahidi, 2004). Besides strong antioxidant activity, phenolic compounds have demonstrated numerous protective effects against chronic diseases, which have recently been reviewed (Shahidi and Yeo, 2018). This section will review only the most recent publications, which report new findings in the hawthorn phytochemistry. In general, the studies were performed for the isolation and purification of flavonoids, other groups of compounds, as well as determination of their variations among different origins and other variables.

Oxidative stress, which reflects an imbalance between the systemic manifestations of reactive oxygen species (ROS), may induce development of various diseases and disorders and, although living cells possess strong endogenous antioxidant system, it is believed that under some conditions ROS-protective function might be insufficient, while exogenous dietary antioxidants could assist in mitigating inflammatory processes and thereby restoring homeostatic state in the organism. In addition, natural antioxidants have attracted an increasing attention as possible alternatives to synthetic additives in foods and cosmetics. Hawthorns are well-known as an excellent source of natural antioxidants as reviewed in the literature (Venskutonis, 2016). The majority of such studies applied simple and easy spectrophotometric in vitro and in situ assays such as DPPH ${ }^{\circ}$ and $\mathrm{ABTS}^{\circ+}$ scavenging, FRAP, Folin-Ciocalteau's reaction (most often considered as TPC), ORAC, $\beta$-carotene-linoleic acid co-oxidation, TBARS and others. Although there is an opinion that such in vitro antioxidant capacity values are not appropriate, the experts in this area recently concluded that they, as lowcost and high-throughput tools, cannot be ignored (Granato et al., 2018). Therefore, together with phytochemical information this section will also briefly reviews the most recent findings in antioxidant properties of hawthorn products.

Phytochemical studies of the most widely used $C$. pinnatifida (Table 2) resulted in separation and purification of 4 new monoterpene glycosides and a new phenolic glycoside in addition to the 10 previously known ones (Li et al., 2015). Furthermore, 15 triterpenoids, including 4 novel acids, in hawthorn berries (Qiao et al., 2015); 2 norditerpenoids with unique carbon skeletons, 4 sesquiterpenoids and 9 nor-sesquiterpenoids from the ethanolic extract of plant leaves (Gao et al., 2017); 8 new phenylpropanoids (crataegusoids A-F) from the fruits (Guo et al., 2018); 8 new lignans (hawthornnins A-H) and 7 known analogues (Huang et al., 2015a); 2 new 8-O-4'-neolignans, huangnin $\mathrm{A}$ and $\mathrm{B}$ and four known analogs (Huang et al., 2015b); 7 new lignans (crataegusnins A-G) and 5 known compounds from the seeds (Peng et al., 2016) and from crude Crataegus Fructus drug (Kazuma et al., 2016), while 7 known main constituents were separated from the flavonoid fraction of leaves using a combination of high-speed counter-current chromatography (HSCCC) coupled with pre-HPLC (Wen et al., 2017). Crataegusins A and B, new flavanocoumarins, also showed 
Table 1. Published review articles on Crataegus spp. bioactive compounds, pharmacological and health effects and safety

\begin{tabular}{lll}
\hline Plants or their products & Topic & Summary of content \\
\hline $\begin{array}{l}\text { Standardized } \\
\text { Crataegus extracts }\end{array}$ & $\begin{array}{l}\text { Treatment of } \\
\text { heart failure }\end{array}$ & $\begin{array}{l}\text { Positive inotropic, chronotropic, dromotropic } \\
\text { effects; negative bathmotropic effects; increases } \\
\text { coronary and myocardial perfusion, lowers } \\
\text { peripheral resistance, has antiarrhythmic } \\
\text { and economizing action with respect to } \\
\text { oxygen and energy consumption. }\end{array}$ \\
& $\begin{array}{l}\text { In combination with D-camphor exerts } \\
\text { a significant effect that counteracts an } \\
\text { orthostatic fall in blood pressure }\end{array}$
\end{tabular}

Hawthorn extract

Clinical trials to treat chronic heart failure

Hawthorn

Cardiovascular disease

Hawthorn medicinal extracts (WS 1442, LI 132)

\section{Standardized extracts} from hawthorn leaves and flowers

\section{Heart failure}

Preclinical and clinical studies mild chronic heart failure

\section{C. oxyacantha}

\section{C. pinnatifida}

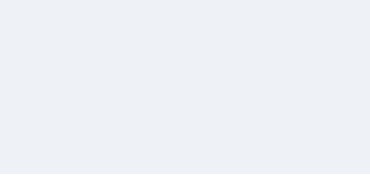

The genus Crataegus

Crataegus spp. of different origins
Chemical constituents, pharmacology, potential applications

Chemical, pharmacological, health, uses aspects

\section{A significant benefit from hawthorn extract as an} adjunctive treatment for chronic heart failure

May induce anti-ischemia/reperfusion-injury, anti-arrhythmic, hypolipidemic and hypotensive effects, which may in part be due to the presence of antioxidant flavonoid components.

Improvement in patients with mild forms of heart failure, clinical symptoms, pressure-heart rate product, left ventricular ejection fraction; no evidence of a notable reduction in mortality or sudden death

Cardiotonic effects, cardio- and vasoprotective properties; may be employed in the prophylactic and therapeutic treatment of endothelial dysfunction, atherosclerosis, coronary heart disease, or prevention of restenosis/reocclusion following peripheral endo-vascular treatment.

A wide range of cardiovascular pharmacological properties: antioxidant activity, positive inotropic effect, anti-inflammatory effect, anticardiac remodeling effect, antiplatelet aggregation effect, vasodilating effect, endothelial protective effect, reduction of smooth muscle cell migration and proliferation, protective effect against ischemia/reperfusion injury, antiarrhythmic effect, lipid-lowering effect and decrease of arterial blood pressure effect

$>150$ compounds (flavonoids, triterpenoids, steroids, monoterpenoids, sesquiterpenoids, lignans, hydroxycinnamic acids, organic acids and nitrogencontaining) have been isolated and identified; broad pharmacological effects with low toxicity; wide applications in pharmacological therapy

Heart (cardiovascular disorders), central nervous system, immune system, eyes, reproductive system, liver, kidney etc; cytotoxic, gastroprotective, anti-inflammatory, anti-HIV and antimicrobial activities. Bioactive phytochemicals: oligomeric procyanidins, flavonoids, triterpenes, polysaccharides, catecholamines; traditional uses; the clinical trials and regulatory status.

Epicatechin, aglycons and glycosides of B-type oligomeric procyanidins and flavonols, phenolic acids and C-glycosyl flavones as he major groups of phenolics; in vitro and animal studies showing cardioprotective, hypolipidaemic, hypotensive, antioxidant, radical-scavenging and anti-inflammatory potentials
Pittler et al., 2003

Chang et al., 2005

Dahmer and

Scott, 2010

Koch and Malek, 2011

Wang et al., 2013

Wu et al., 2014

Kumar et al., 2012

Yang and Liu, 2012 
Table 1. Published review articles on Crataegus spp. bioactive compounds, pharmacological and health effects and safety - (continued)

\begin{tabular}{|c|c|c|c|}
\hline Plants or their products & Topic & Summary of content & Reference \\
\hline C. oxycantha & $\begin{array}{l}\text { Treatment of atrial } \\
\text { fibrillation }\end{array}$ & $\begin{array}{l}\text { Mechanisms of cardiovascular health benefits; lack of } \\
\text { clinical studies evaluating its use in atrial fibrillation }\end{array}$ & $\begin{array}{l}\text { Kanman-thareddy } \\
\text { et al., } 2015\end{array}$ \\
\hline C. monogyna Jacq. & $\begin{array}{l}\text { Polyphenolic } \\
\text { composition and } \\
\text { medical applications }\end{array}$ & $\begin{array}{l}\text { A critical review about physiological and } \\
\text { pharmacological activities due to the presence } \\
\text { of different bioactive natural compounds. In } \\
\text { addition, scientific evidence suggests that } \\
\text { the toxicity of hawthorn is negligible }\end{array}$ & Nabavi et al., 2015 \\
\hline Hawthorn juice & Various aspects & $\begin{array}{l}\text { Nutritional characteristics, bioactives and } \\
\text { antioxidant efficacy, phenolics, health effects, } \\
\text { novel products/formulations and future trends }\end{array}$ & Venskutonis, 2016 \\
\hline Crataegus extract WS 1442 & Benefit-risk assessment & $\begin{array}{l}\text { Positive inotropic and antiarrhythmic properties; } \\
\text { protecting from ischemic damage, reperfusion } \\
\text { injury, and hypertension-related hypertrophy; } \\
\text { improving endothelial functions (NO synthesis, } \\
\text { delay of endothelial senescence); favorable safety } \\
\text { profile (monotherapy and as add-on therapy); no } \\
\text { drug interactions; no specific adverse reactions }\end{array}$ & Holubarsch et al., 2018 \\
\hline $\begin{array}{l}\text { WS } 1442 \text { extract from } \\
\text { Crataegus spp. leaves } \\
\text { and flowers with } 18.75 \% \\
\text { oligomeric procyanidins }\end{array}$ & $\begin{array}{l}\text { Effects on } \\
\text { cardiovascular system } \\
\text { in vitro and in vivo, } \\
\text { inc. large clinical trials }\end{array}$ & $\begin{array}{l}\text { Beneficial cardioprotective values; free radicals } \\
\text { scavenger; protect the ischemic heart tissue } \\
\text { from neutrophile elastase action successions; } \\
\text { vasorelaxant activity, via affecting eNOS synthase, } \\
\text { and prevents ischemic heart tissue swelling by } \\
\text { influence on calcium signaling pathways, and } \\
\text { thus detain hyperpermeability of endothelium. }\end{array}$ & Zorniak et al., 2017 \\
\hline Crataegus spp. & $\begin{array}{l}\text { Phenolic compounds; } \\
\text { their bioactivity }\end{array}$ & $\begin{array}{l}\text { Beneficial effects and the mechanisms of } \\
\text { action involved are analyzed in a critical and } \\
\text { systematic way in order to promote its use in } \\
\text { the treatment of various diseases considered } \\
\text { in Mexico as public health problems. }\end{array}$ & $\begin{array}{l}\text { Cervantes-Paz } \\
\text { et al., } 2018\end{array}$ \\
\hline C. meyeri and C. pontica & $\begin{array}{l}\text { Antioxidant properties } \\
\text { and medicinal uses }\end{array}$ & $\begin{array}{l}\text { The advantages of using natural remedies over their } \\
\text { synthetic equivalents, the necessity of thorough } \\
\text { investigations of less studied Crataegus spp }\end{array}$ & $\begin{array}{l}\text { Dolatkhani and } \\
\text { Jameie, } 2015\end{array}$ \\
\hline
\end{tabular}

a significant $\mathrm{DPPH}^{\bullet}$ reducing activity compared with epicatechin (Kazuma et al., 2016). Most of the compounds isolated from the $70 \%$ ethanolic extract of $C$. pinnatifida seeds showed moderate $\mathrm{DPPH}^{\circ}$ scavenging activity and significant activities in the FRAP and ABTS assays. Furthermore, 6 compounds exhibited marked NO inhibition, 4 of them had a potent TNF- $\alpha$ inhibitory effect indicating that hawthorn seeds can be regarded as a potential new and cheap source of antioxidants and inflammation inhibitors (Peng et al., 2016). From $C$. pinnatifida, the isolated lignans demonstrated $\mathrm{DPPH}^{*} / \mathrm{ABTS}^{\cdot+}$ scavenging efficacy, while some of them had anti-inflammatory activities, which was assessed by detecting the NO and TNF- $\alpha$ production in the LPS-induced RAW264.7 cells (Huang et al., 2015a). The fractions isolated with different polarity solvents from the crude $70 \%$ aqueous acetone extract of wood and bark of $C$. pinnatifida demonstrated antioxidative and anti-inflammatory activities. Thus, the n-butanol and ethyl acetate fractions of wood and bark, respectively, exhibited the strongest antioxidant effects, while all moisture-free fractions of wood showed high inhibitory effect on NO production (Bae and Kim, 2017).

Seasonal variations (May-October) in the yield of 7 phenolic compounds, the TPC in C. pinnatifida leaves, roots, twigs, and fruits were positively correlated with the temperature and length of daytime, while most remarkable radical scavenging and reducing power was determined for the leaves harvested in September (Luo et al., 2016).

Several articles have reported phytochemical studies of $C$. azarolus (Table 2). Thus, ethanolic extract of C. azarolus var. euazarolus Maire leaves was fractionated with different solvents and it was found that ethanol extract $(70 \%)$ showed the highest $\mathrm{DPPH}^{\circ}$ scavenging activity compared to methanol, ethyl acetate and acetone extracts (Abu-Gharbieh and Shehab, 2017). A new ursanetype triterpene acid, named azarolic acid, and 8 known compounds were isolated from the crude ethyl acetate extract of $C$. azarolus var. aronia (Mahmud et al., 2016). Phytochemical composition of 20 phenolic compounds quantified in C. azarolus and C. monogyna fruits were compared (Mraihi et al., 2015). Methanol and ethanol extracts of C. azarolus exerted substantial antioxidant, anti-inflammatory, and antiproliferative capacities, which were evaluated by measuring the secreted amounts of the proinflammatory mediator prostaglandin E2 (PGE2), and by assaying the mRNA levels of the proinflammatory cytokines (IL- $\alpha$, IL- $\beta$, and Il-6), chemokines (CCL3 and CCL4) and inflammation-sensitive COX2 and iNOS enzymes (Kallassy et al., 2017).

Dibenzo- $p$-furan derivatives and ursolic acid were isolated from 
Table 2. Phytoconstituents of Crataegus spp. (recently reported; newly identified compounds are in italics)

\begin{tabular}{|c|c|c|c|}
\hline Sample information & Name & $\begin{array}{l}\text { Bioactivities, other } \\
\text { study objective }\end{array}$ & Reference \\
\hline C. pinnatifida, extract of leaves & 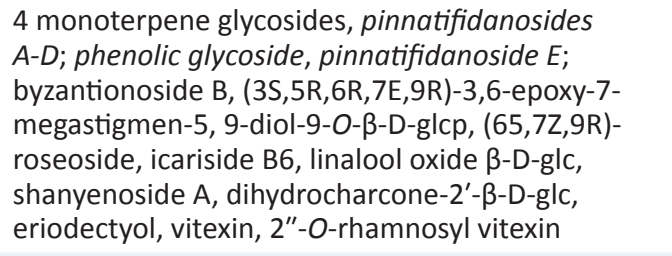 & Antithrombotic effects & Li et al., 2015 \\
\hline $\begin{array}{l}\text { C. pinnatifida, ethanolic } \\
\text { extract of leaves }\end{array}$ & 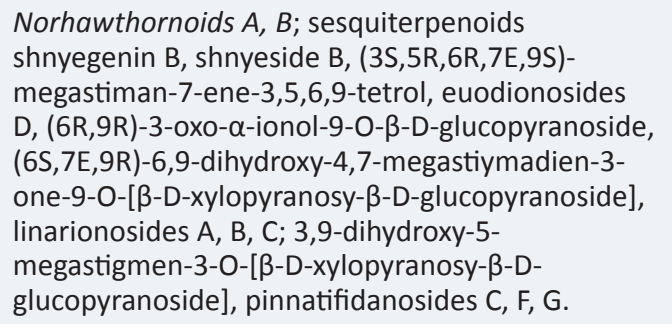 & Antithrombotic effects & Gao et al., 2017 \\
\hline $\begin{array}{l}\text { C. pinnatifida, hydroethanolic } \\
\text { extract of fruits }\end{array}$ & Crataegusoids: A(-), B, C, D, E (-) and (+), F & $\begin{array}{l}\text { Cytotoxicity against } \\
\text { cancer cells }\end{array}$ & Guo et al., 2018 \\
\hline C. pinnatifida, extract of seeds & $\begin{array}{l}8 \text { new lignans, hawthornnins } A-H \\
\text { and } 7 \text { known analogues }\end{array}$ & $\begin{array}{l}\text { Antioxidant and } \\
\text { anti-inflammatory }\end{array}$ & Huang et al., 2015a \\
\hline C. pinnatifida, extract of seeds & $\begin{array}{l}2 \text { new } 8-0-4^{\prime} \text { neolignans, huangnin } \\
A \text { and } B ; 4 \text { known analogs }\end{array}$ & Tyrosinase inhibition & Huang et al., 2015b \\
\hline $\begin{array}{l}\text { C. pinnatifida, } 70 \% \text { ethanol } \\
\text { extract of seeds }\end{array}$ & $\begin{array}{l}7 \text { Crataegusnins A-G; } 3 \text { substituted } \\
\text { propanetriols (3); leptolepisol D }\end{array}$ & $\begin{array}{l}\text { Antioxidant and } \\
\text { anti-inflammatory }\end{array}$ & Peng et al., 2016 \\
\hline $\begin{array}{l}\text { Crataegus spp., } 70 \% \text { ethanol } \\
\text { extract from seeds }\end{array}$ & $\begin{array}{l}(7 R, 8 R, 8 S)-,\left(7^{\prime} S, 8^{\prime} R, 8 R\right)-,\left(7^{\prime} R, 8^{\prime} S, 8 S\right) \text { - } \\
\text { isolariciresinols, }\left(7^{\prime} S, 8^{\prime} R, 8 R\right) \text {-lyoniresinol, }\left(7^{\prime} S, 8^{\prime} R \text {, }\right. \\
8 R) \text {-isolariciresinol-9'-8-D-glc, lyoniside, nudiposide }\end{array}$ & $\begin{array}{l}\text { Inhibition of amyloid } \\
A_{\beta 1}-42 \text { aggregation }\end{array}$ & Huang et al., 2018b \\
\hline $\begin{array}{l}\text { C. pinnatifida, flavonoid } \\
\text { extract of leaves }\end{array}$ & $\begin{array}{l}\text { (-)-Epicatechin, quercetin-3-O-(2,6-di- } \alpha \text {-L- } \\
\text { rhamnopyranosyl)- } \beta \text {-D-galactopyranoside, } \\
4^{\prime \prime}-O \text {-glucosyl and } 2^{\prime \prime}-O \text {-rhamnosylvitexins, } \\
\text { vitexin, hyperoside and isoquercitrin }\end{array}$ & $\begin{array}{l}\text { Isolation and } \\
\text { purification of } \\
\text { flavonoids }\end{array}$ & Wen et al., 2017b \\
\hline $\begin{array}{l}\text { C. pinnatifida var. major, crude } \\
\text { Crataegus Fructus drug }\end{array}$ & Crataegusins $A$ and $B(2)$ (new flavanocoumarins) & DPPH reducing activity & Kazuma et al., 2016 \\
\hline $\begin{array}{l}\text { C. azarolus var. eu-azarolus } \\
\text { Maire, ethanol extract of } \\
\text { leaves and its fractions }\end{array}$ & $\begin{array}{l}\text { EtOH: rutin, salicylic and ellagic acids; chloroform } \\
\text { and } n \text {-butanol fractions: ursolic, } 3-\beta-O-\text {-acetyl } \\
\text { ursolic, and ellagic acids, quercetin-3-O- } \beta \text { methyl } \\
\text { ether, rutin and apigenin7-O-rutinoside }\end{array}$ & $\begin{array}{l}\text { Anti-hyperglycemic } \\
\text { activity }\end{array}$ & $\begin{array}{l}\text { Abu-Gharbieh } \\
\text { Shehab, } 2017\end{array}$ \\
\hline $\begin{array}{l}\text { C. azarolus var. aronia, ethyl } \\
\text { acetate extract of leaves }\end{array}$ & $\begin{array}{l}\text { A new ursane-type triterpene acid, } \\
\text { azarolic acid, } 4 \text { known phenolic } \\
\text { compounds; } 4 \text { known triterpene acids }\end{array}$ & Anti-vasoconstriction & $\begin{array}{l}\text { Mahmud et } \\
\text { al., } 2016\end{array}$ \\
\hline C. monogyna, C. azarolus fruit & $\begin{array}{l}3 \text { hydroxycinnamic and } 1 \text { hydroxybenzoic } \\
\text { acid, } 6 \text { glucosylated flavonols and } 2 \text { flavones, } \\
2 \text { cyanidin glycosides; (-)-epicatechin, a } \\
\text { dimer B2, two trimers, C1 and C } 2 \text {. }\end{array}$ & $\begin{array}{l}\text { Phytochemical } \\
\text { characterization }\end{array}$ & Mraihi et al., 2015 \\
\hline C. pycnoloba, total extract & $\begin{array}{l}4 \text { dibenzofurans inc. newly discovered } \\
\text { compound 6-hydroxy-2,3,4- } \\
\text { trimethoxydibenzofuran; ursolic aldehyde. }\end{array}$ & $\begin{array}{l}\text { Melanin synthesis } \\
\text { inhibition }\end{array}$ & Agalou et al., 2018 \\
\hline $\begin{array}{l}\text { C. oxyacantha, shade } \\
\text { dried plant twigs }\end{array}$ & $\begin{array}{l}\text { 2-(3, 4-dimethoxyphenyl)-2-methoxyethanol, } \\
\text { 3-hydroxy-1-(4-hydroxy-3-methoxyphenyl propan- } \\
\text { 1-one, } \beta \text {-sitosterol-3-O- } \beta \text {-D-glc, lupeol, } \beta \text {-sitosterol, } \\
\text { betulin, betulinic and oleanolic acids, chrysin (9); }\end{array}$ & $\begin{array}{l}\text { Inhibition of acetyl and } \\
\text { butyryl-cholinesterases }\end{array}$ & Ali, et al., 2017 \\
\hline $\begin{array}{l}\text { Crataegus spp. from Bosnia, } \\
\text { leaves with flowers, and berries }\end{array}$ & $\begin{array}{l}\text { In mg/g DW: gallic acid (0.001-0.082), chlorogenic } \\
\text { acid }(0.19-8.70 \text {, rutin (0.03 to } 13.49) \text {. }\end{array}$ & $\begin{array}{l}\text { Phytochemical } \\
\text { characterization }\end{array}$ & Čulum et al., 2018 \\
\hline
\end{tabular}


Table 2. Phytoconstituents of Crataegus spp. (recently reported; newly identified compounds are underlined) - (continued)

\begin{tabular}{|c|c|c|c|}
\hline Sample information & Name & $\begin{array}{l}\text { Bioactivities, other } \\
\text { study objective }\end{array}$ & Reference \\
\hline $\begin{array}{l}\text { C. pubescens, Fruit pulp } \\
\text { (from Mexico) }\end{array}$ & $\begin{array}{l}\text { In mg/100 mg DW: (+)-catechin } \\
(9.17 \pm 0.20),(-) \text {-epicatechin }(4.32 \pm 0.11) \text {, } \\
\text { chlorogenic acid }(5.60 \pm 0.24 \mathrm{mg} / 100) ; \text { total } \\
\text { proanthocyanidins } 84.6 \pm 1.4 \mathrm{mg} \text { cyanidin; } \\
\text { total flavonoids } 55.89 \pm 1.43 \mathrm{mg} \text { quercetin. }\end{array}$ & $\begin{array}{l}\text { Phytochemical } \\
\text { characterization }\end{array}$ & $\begin{array}{l}\text { González-Jiménez } \\
\text { et al., } 2018\end{array}$ \\
\hline $\begin{array}{l}\text { C. microphylla Koch. ssp. } \\
\text { malyana K. I. Chr. \& Janjic, } \\
\text { extracts of leaves with flowers }\end{array}$ & $\begin{array}{l}\text { In } \mathrm{mg} / \mathrm{g} \text { DW: gallic acid } 0.04 \text {, caffeic } \\
\text { acid0.60, and hyperoside } 2.61 ; \text { TPC: } 2.47 \\
\text { to } 13.35 \text { GAE; TFC: } 0.01-1.09 \text { QE }\end{array}$ & $\begin{array}{l}\text { Phytochemical } \\
\text { characterization }\end{array}$ & $\begin{array}{l}\text { Čopra-Janićijević } \\
\text { et al., } 2018\end{array}$ \\
\hline $\begin{array}{l}\text { Various Crataegus spp., } \\
\text { flowers and leaves of } 56 \\
\text { samples from Iran }\end{array}$ & $\begin{array}{l}\text { TPC: } 7.21-87.73 \mathrm{mg} \mathrm{GAE} / \mathrm{g} \mathrm{DW} \text {; TFC: } \\
2.27-17.40 \mathrm{mg} / \mathrm{g} \mathrm{DW} \text {; chlorogenic acid, } \\
\text { vitexin-2-O-rhamnoside, vitexin, rutin, } \\
\text { hyperoside, quercetin, isoquercetin }\end{array}$ & $\begin{array}{l}\text { Flavonoids profile, } \\
\text { antioxidant activity }\end{array}$ & Alirezalu et al., 2018 \\
\hline $\begin{array}{l}\text { C. almaatensis Pojark, } \\
\text { leaves, flowers and fruits }\end{array}$ & $\begin{array}{l}22 \text { secondary metabolites (flavonoids } \\
\text { and phenolic acids); TPC: } 218 \mathrm{mg} / \mathrm{g}\end{array}$ & $\begin{array}{l}\text { Copmparison with } \\
\text { C. oxyacantha }\end{array}$ & $\begin{array}{l}\text { Bekbolatova } \\
\text { et al., } 2018\end{array}$ \\
\hline $\begin{array}{l}\text { C. pinnatifida, } \\
\text { commercial berries }\end{array}$ & $\begin{array}{l}15 \text { triterpenoids, inc. } 4 \text { novel hydroxy-olean- } \\
\text { 12-en-28-oic (HOA) acids: } 3-\beta, 6 \beta, 18 \beta \text {-triHOA, } \\
3 \beta, 6 \beta, 18 \beta, 23 \text {-tetra HOA, } 2 \alpha, 3 \beta, 6 \beta, 18 \\
\beta \text {-HOA, } 2 \alpha, 3 \beta, 6 \beta, 18 \beta, 23 \text {-pentaHOA }\end{array}$ & $\begin{array}{l}\text { Antiproliferative and } \\
\text { antioxidant activity }\end{array}$ & Qiao et al., 2015 \\
\hline $\begin{array}{l}\text { Fruits, methanol, ethanol, } \\
\text { acetone (80\%) water extracts }\end{array}$ & $\begin{array}{l}\text { Water (mg/g): vanillic (0.093), gallic (0.279) } \\
\text { acids, catechin (3.622), chlorogenic ( } 1.457 \\
0.058) \text { and ferulic (6.909) acid; acetone: } \\
\text { epicatechin (2.71), protocatechuic acid (5.827) }\end{array}$ & $\begin{array}{l}\text { Effect of solvents, } \\
\text { antioxidant, } \\
\alpha \text {-glucosidase } \\
\text { inhibitory activity }\end{array}$ & Miao et al., 2016 \\
\hline $\begin{array}{l}\text { Crataegus spp., of } \\
\text { leaves and flowers }\end{array}$ & $\begin{array}{l}81 \text { components: benzaldehyde ( } 82.54 \%) \\
\text { butyraldehyde (38.27\%), (E)2-hexenal ( } 21.67 \%)\end{array}$ & $\begin{array}{l}\text { Volatile, components, } \\
\text { aroma }\end{array}$ & Ozderin et al., 2016 \\
\hline C. pinnatifida, & $\begin{array}{l}\text { GC area \%: Methyl acetate ( } 4.40), \text { n-hexane } \\
(2.90), 2 \text {-methyl-furan }(1.80), \text { 3-methyl- } \\
\text { butyraldehyde (3.64), hexanal ( } 2.08), \\
\text { furaldehyde (5.77), D-limonene ( } 7.99)\end{array}$ & $\begin{array}{l}\text { Volatile compounds, } \\
\text { aroma }\end{array}$ & Zhong et al., 2015 \\
\hline $\begin{array}{l}\text { Hawthorn, pharmaceutical } \\
\text { forms of inflorescence }\end{array}$ & $\begin{array}{l}\text { Essential oil (\%): } 0.05 \text { to } 0.20 \% \mathrm{v} / \mathrm{w} \text {; tricosane } \\
(12-17),(11-16),(6-11), n \text {-hexadecanoic } \\
\text { acid (1-11), nonadecane (3-7), (E,E)- } \alpha- \\
\text { farnesene (1-5), caryophyllene oxide } \\
\text { (1-4), methyl eugenol (up to } 6) \text {. }\end{array}$ & Essential oil, aroma & Kowalski et al., 2018 \\
\hline
\end{tabular}

Abbreviations are: glcp,glucopyranoside; glc, glucoside; TPC,total phenolic content; TFC,total flavonoid content; GAE,gallic acid equivalents; and QE, quercetin equivalents.

C. pycnoloba extract, including the atom numbering of the newly discovered compound (Agalou et al., 2018); 9 compounds were isolated from $C$. oxyacantha, including 2 new natural products (Ali et al., 2017). Selected phytochemicals and antioxidant potential were studied in the C. monogyna ethanolic extracts from bark, leaves and berries: the highest TPC, radical scavenging potency as well as the levels of oleanolic acid, quercetin and lupeol were found in the bark extract, while the highest ursolic acid content was in the berries extract (Rezaei-Golmisheh et al., 2015).

The main phenolics in ethanolic extracts of leaves and berries of $C$. orientalis Pall. ex M. Bieb. from F.Y.R. Macedonia were hyperoside, isoquercitrin and chlorogenic acid (Šavikin et al., 2017), while vitexin and hyperoside, commonly found in chemotaxonomic investigations of Crataegus spp., were not detected in dry leaves with flowers, and berries of $C$. rhipidophylla Gand., $C . \times$ subsphaericea Gand., and C. $\times$ macrocarpa Hegetschw grown in Bosnia (Čulum et al., 2018). The presence of polymeric polyphenols (procyanidin dimers, trimers, and tetramers) in C. pubescens fruit from Mexico was reported for the first time (González-Jiménez et al., 2018). The composition and antioxidant activity in vitro were reported for different extracts of $C$. microphylla Koch subsp. malyana K. I. Chr. and Janjic; interestingly, the Soxhlet extract of leaves with flowers was best in $\mathrm{DPPH}^{*}$ scavenging $\left(\mathrm{IC}_{50}=0.78\right.$ $\mathrm{mg} / \mathrm{mL}$ ) while that of berries was stronger as $\mathrm{ABTS}^{++}$scavenger with $\mathrm{IC}_{50}$ of $0.39 \mathrm{mg} / \mathrm{mL}$ (Čopra-Janićijević et al., 2018). TPC in methanol extracts of $C$. monogyna from nine different locations in central Spain was in the range of 117.7-204.3 mg GAE/g extract, the amounts of chromatographically quantified flavonoids and phenolic acids was $23.3-143.3 \mathrm{mg} / \mathrm{kg}$, while ORAC and $\mathrm{IC}_{50}$ of $\mathrm{DPPH}^{*}$ scavenging values were $1.32-2.76 \mathrm{~mol} \mathrm{TE} / \mathrm{mg}$ and $0.82-3.76 \mathrm{~g} / \mathrm{mL}$, respectively (Abuashwashi et al., 2016). TPC and $\mathrm{DPPH}^{\circ}$ scavenging activity as well as the contents of metals $(\mathrm{Zn}$, $\mathrm{Fe}, \mathrm{Cu}, \mathrm{Mn}, \mathrm{Cd}, \mathrm{Cr}$, and $\mathrm{Pb}$ ) were reported in wild $C$. oxyacantha from Serbia (Veličković et al., 2016).

Chlorogenic acid, hyperoside, and rutin were the most abundant phenolics in the extracts of hawthorn flowers in most genotypes of 56 studied Crataegus spp. samples collected from different geographical regions of Iran (Alirezalu et al., 2018). The composition of 22 secondary metabolites (flavonoids and phenolic acids) in leaves, flowers and fruits of endemic in Kazakhstan C. almaatensis 
Pojark was compared with a well-known $C$. oxyacantha flowers. Leaf extracts were the richest sources of metabolites (TPC $=218$ $\mathrm{mg} / \mathrm{g})$ and the most active DPPH' scavengers $\left(\mathrm{IC}_{50}=48 \mu \mathrm{g} / \mathrm{mL}\right)$, while the flowers of the Kazakh species were as rich in polyphenols as the C. oxyacantha (Bekbolatova et al., 2018).

Evaluation of 18 hawthorn genotypes selected from repository collection in Malatya province (Turkey) belonging to several Crataegus spp. revealed that the genotype 44MA12 (C. monogyna subsp. azarella) had the highest anthocyanin content (516 mg per $100 \mathrm{~g}$ fresh fruit) and the strongest $\mathrm{DPPH}^{\bullet}$ scavenging capacity, while the genotype 44MA11 (C. meyeri) had the highest TPC, 3,460 mg GAE/100 g fresh fruit (Ercisli et al., 2015). Thirty-five compounds were isolated from $C$. dahurica methanol extract for the first time and their structures identified as triterpenoids and polyphenolics as the main components (Wang et al., 2018). Evaluation of antioxidant activities, TPC, TPF of crude methanolic extract and its fractions (ethyl acetate, diethyl ether, and chloroform) obtained from Algerian C. azarolus showed that the aerial parts extracts of this species are a good source of natural antioxidants (Lakache et al., 2016). Anthocyanin composition of different wild and cultivated berry species including Chinese hawthorn were quantified by Veberic et al. (2015). Thirty six compounds were reported in different extracts of hawthorn fruit, 15 of them were tentatively identified in hawthorn fruits for the first time (Miao et al., 2016). TPC, condensed tannin content and $\mathrm{DPPH}^{*} / \mathrm{ABTS}^{*+}$ scavenging capacities were higher for fruit extracts of $C$. pinnatifida Bge. var. major N. E. Br. (Shanlihong) than for the other two Chinese hawthorn varieties, namely $C$. pinnatifida Bge. (Shanzha) and $C$. pinnatifida Bge. var. pinnatifida (Dou et al., 2015). The advantages of Shanlihong variety, which exhibited elevated levels of TPC and TFC, including free and bond phenolics (procyanidin B-2 epicatechin, chlorogenic acid, hyperoside, and isoquercitrin), were also reported by Wen et al. (2015). Among the three tested varieties, the ORAC, and hydrophilic peroxyl radical scavenging capacity of the free faction were $398.3-555.8 \mu \mathrm{mol} \mathrm{TE} / \mathrm{g} \mathrm{DW}$, and 299.1-370.9 $\mu \mathrm{mol}$ vitamin $\mathrm{C}$ equivalents/g DW, respectively, while the corresponding cellular antioxidant activity (CAA) values were $678-1,200 \mu \mathrm{mol}$ of $\mathrm{QE} / 100 \mathrm{~g}$ DW in the no PBS wash protocol, and 345.9-532.9 $\mu \mathrm{mol}$ of QE/100 g DW in the PBS wash protocol. Finally, the fruits of $C$. pinnatifida were subjected to in vitro digestion and it was determined that 37.41 and $31.51 \mathrm{mg}$ GAE/g DW of TPC were released for Shanlihong and Dajinxing, respectively, while procyanidin $\mathrm{B} 2$, epicatechin, chlorogenic acid and catechin were the major released flavonoids. ORAC and peroxyl radical scavenging capacity well correlated with the released TPC or flavonoids (Zheng et al., 2018).

Some studies have reported the volatile compounds of hawthorn although the content of essential oil in Crataegus spp. is usually very low. For instance, in 4 tested pharmaceutical forms of hawthorn inflorescence it was from 0.05 to $0.20 \%(\mathrm{v} / \mathrm{w})$ and composed mainly of long chain hydrocarbons (Kowalski et al., 2018). Zhong et al. (2015) identified 46 volatile compounds in $C$. pinnatifida with contents higher than $1 \%$ in the total GC area by HS-SPME coupled with GC-MS. The contents of furaldehyde, 5-methylfuraldehyde, methyl acetate, 2-methylbutyraldehyde, D-limonene and 2-methylfuraldehyde significantly changed after stir-frying and it might be important in odor changes. Volatile components were also reported in C. pentagyna subsp. pentagyna, C. orientalis subsp. orientalis, $C$. orientalis subsp. szovitsii, C. tanacetifolia, $C$. azarolus var. aronia, C. monogyna var. lasiocarpa, C. monogyna var. monogyna leaf and flower samples collected from different provinces of Western Anatolia (Ozderin et al., 2016).

The changes of phytochemicals during processing and storage were also studied. "Xinglongzirou" hawthorn wine bioactives and antioxidant capacity were determined during production and storage. Only six anthocyanins were detected after fermentation. Microwaving and heating pretreatments significantly increased the total amount of anthocyanin and antioxidant capacity values in the stored hawthorn wine while the TPC decreased (Liu et al., 2018). Heat and microwave pretreatments had also a significant impact on anthocyanins in hawthorn drink; more of them remained after heat treatment than after microwaving $(0.745 \mathrm{mg} / 100 \mathrm{~mL})$; these were $52.4 \%$ higher than those in the control group after storage for 7 days (Liu et al., 2016). Chemometric methods (spectrophotometry and HPLC) were successfully applied to differentiate raw and processed Crataegi Fructus (Fei et al., 2018). Significant differences in physicochemical characteristics associated with fruit quality and free amino acids were found during maturation of hawthorn fruits; for instance, the content of moisture, total soluble sugars, soluble pectin, reduced ascorbic acid, total ascorbic acid, fructose, and sucrose increased while crude protein content decreased significantly (Li et al., 2015).

Some studies were evaluating extraction methods. In general, selection of extraction solvents and procedures may have different goals, e.g. obtaining high total yields or recovery target bioactive fractions/constituents. Ethanol and water, as the most friendly and effective polar solvents, have been most widely used for food, natural pharmaceuticals and cosmetics. For instance, different ethanol concentrations $(0-100 \%)$ were applied for $C$. pinnatifida and the yields were $19.03,33.16,27.79,21.88$, and $21.71 \%$ at $100,70,50$, 30 and $0 \%$ (water) concentration, however the highest TPC and $\mathrm{DPPH}^{*} / \mathrm{ABTS}^{*+}$ scavenging capacity was obtained in case of $50 \%$ (Kang, 2015). The technical and economic advantages of pressurized hot water $\left(90{ }^{\circ} \mathrm{C}\right)$ extraction of $C$. monogyna compared to traditional percolation with ethanol and water $(70: 30, \mathrm{v} / \mathrm{v})$ was shown by successful incorporation of natural batch variability into the physico-chemical process modelling concept (Sixt and Strube, 2018). Matrix solid-phase dispersion process was also suggested as a good alternative to the classic methods for extracting polyphenols from $C$. oxyacantha fruits and leaves, although phenolic profile was solvent-dependent (Benabderrahmane et al., 2018). In addition, this study claimed that epicatechin gallate, caftaric acid and orientin were not previously reported in this species. Ultrasonic assisted extraction (UAE) using an alkyl polyglycoside surfactant and further separation and purification with commercial macroporous resins was shown as an effective techniques for recovery of vitexin and its 2 "-O-rhamnoside from the leaves (Han et al., 2016a). The extract obtained by UAE from $C$. pinnatifida fruits demonstrated higher TPC, TFC and $\mathrm{DPPH}^{*}$ scavenging capacity (Park et al., 2017b). Aqueous solutions of citric acid and methanol were compared for C. monogyna fruit; it was found that the former was favorable in terms of total yield, TPC and ascorbic acid, while $\mathrm{DPPH}^{\bullet}$ and $\mathrm{ABTS}^{*+}$ scavenging capacity was not dependent on the solvent (Pliszka et al., 2016). Hawthorn seeds, as a byproduct of manufacturing hawthorn juice and jam, were evaluated as a potential new and cheap source of antioxidants and inflammation inhibitor (Huang et al., 2015).

A protocol for preparative isolation of oligomeric and polymeric procyanidins from an acetone-water extract of Crataegi folium cum fore was developed, yielding procyanidin reference clusters with defined degree of polymerization (DP) from 2 to 10 (Hellenbrand et al., 2015). In addition, monitoring of procyanidin distribution during seasonal growth of fresh $C$. monogyna plants showed that their contents were between 20 and $55 \mathrm{mg} / \mathrm{g}$ DW of oligomeric procyanidins during the growing season in the different plant organs with strong accumulation in the flowers and fruits (55 $\mathrm{mg} / \mathrm{g}$ DW). Regarding other components, the viscoelastic behavior and texture profile of gels, composed of the high methoxypectin in 
hawthorn, were compared with commercial citrus gels (LinaresGarcia et al., 2015); the homogenous polyphenolic-polysaccharide conjugates $\left(\mathrm{MW}>760 \times 10^{3}\right.$ and $970 \times 10^{3} \mathrm{~g} / \mathrm{mol}$ ) containing some flavonoid units and rich in galacturonic acid with low esterification degree were isolated from flowers and fruits of C. monogyna (Pawlaczyk-Graja, 2018).

\section{Cardioprotective benefits}

Cardiovascular health benefits of various Crataegus drugs and other preparations have been most widely studied. In addition, the potential role of hawthorn in cardiovascular diseases was specifically reviewed by Chang et al. (2005). Hawthorn extracts have been used for this purpose in many countries, particularly against mild forms of chronic heart failure. For instance, search word combination Crataegus +cardiovascular in Clavirate Analytics Web of Science (WoS) since 1980 gave 286 records, and even during last 4 years (since 2015) the number of publications on this topic remains quite high, 61 (accessed on December 7, 2018). Consequently, the interest in hawthorn as a source of natural cardioprotective medicine, nutraceutical and functional food is evident.

Hawthorn extract WS 1442 containing a range of pharmacologically active substances including oligomeric proanthocyanidins and flavonoids is, possibly, the most famous Crataegus fruit-based drug with 89 and 14 records in WoS since 1980 and 2015, respectively. Moreover, two most recent articles reviewed WS 1442 in terms of experimental and clinical experiences (Zorniak et al., 2017) and benefit-risk assessment (Holubarsch et al., 2018). Therefore, only those studies, which were not reviewed in these publications, will be covered briefly. Thus, Fuchs et al. (2017) reported that WS 1442 protective effects against mild forms of chronic heart failure dysfunction may be due to the promotion of endothelial barrier integrity and inhibition of endothelial hyperpermeability, which are exerted by activating barrier enhancing (cortactin activation) and blocking barrier disruptive (calcium signaling) pathways, respectively. Bioactivity-guided fractionation of WS 1442 using successive elution with water, 95\% ethanol, methanol, and $70 \%$ acetone, revealed that only the ethanolic fraction interfered with calcium signaling and only the methanolic fraction led to an activation of cortactin. Moreover, the role of phenolic compounds was excluded from the calcium active substance, whereas cortactin activation was attributed to oligomeric procyanidins with a distinct degree of polymerization (Fuchs et al., 2017). The study with human umbilical vein endothelial cells (HUVECs) exposed to TNF- $\alpha$, with or without simvastatin (positive control) and WS 1442, suggested that the factors upregulating miR-155 expression, which decreases eNOS expression and endothelial function impairment, may be mitigated by WS 1442 (Wang et al., 2018). The results demonstrated that both TNF- $\alpha$ and WS 1442 increased miR-155 expression and decreased eNOS expression, however, unlike TNF- $\alpha$, WS 1442 increased phosphorylated eNOS expression and NO concentrations and mitigated the overall negative effect of miR-155. Protecting effects of total flavones of hawthorn combined with resveratrol on the endothelial cells injury after artery bypass graft surgery were demonstrated in the study with rabbits, which determined that the level of circulating endothelial cells, density and the expressions of albumen and mRNA of ICAM-1 were significantly decreased (Zhu et al., 2018). It was also reported that WS (R) 1442 improved vascular function in diet-induced obese mice (Xia et al., 2016). The activity of WS 1442 in stimulating cardiomyocyte differentiation from murine and human embryonic stem cells (ESC) after forming mesoderm was validated in a mESC-based spontaneous differentiation assay, while bioassay-guided fractionation suggested that this activity is exerted by specific classes of compounds (Halver et al., 2015). Aerobic exercise and administration of $C$. oxyacantha extract reduced ICAM-1 and E-selectin in serum levels of 80 stable angina pectoris patients and such combined treatment was suggested as an effective complementary strategy for lowering the risk of atherosclerosis and heart problems (Jalaly et al., 2015).

The cardiac effects of hydroalcoholic extract of $C$. pentagyna leaf as well as isoquercetin and vitexin were studied using cardiomyocytes differentiated from healthy human embryonic stem cells, namely long QT syndrome type 2 and catecholaminergic polymorphic ventricular tachycardia type 1 (CPVT1) patient-specific induced pluripotent. It was concluded that tested preparations may be introduced as a novel nutraceutical with antiarrhythmic potential for CPVT1 patients (Pahlavan et al., 2018). The effects of polyphenolic extracts of $C$. pentagyna and $C$. microphylla fruits on hypoxia, which is a state of oxygen deficiency occurring in heart diseases, ischemia, bleeding and heart attack, were studied using male Swiss albino mice model. It was found that the extracts exhibited significant anti-hypoxic activity and prolonged animal survival time (Ebrahimzadeh et al., 2018). The activity of these extracts was attributed to a high TPC, 1,136.0 and 721.1 GAE mg/g in C. pentagyna and C. microphylla, respectively. Polyphenolicpolysaccharide conjugates from flowers and fruits of C. monogyna prolonged the plasma coagulation process in in vitro tests, even at a concentration of $31.25 \mu \mathrm{g} / \mathrm{mL}$; however, only the product from flowers was highly selective in its action. It was mainly the indirect inhibitor of factor Xa, mediated by antithrombin, where such mechanism of activity is typical for highly sulfated glycosaminoglycans (Pawlaczyk-Graja, 2018).

Flavonoid-rich preparations of $C$. pinnatifida leaves (HLF) have been used to treat cardiovascular diseases; however, their ability to attenuate atherosclerosis development and possible mechanism are not evident. To fill this gap, Dong et al. (2017) by the large scope in vivo studies using apoE knockout mice showed that administration of HLF resulted in the following effects: (1) reduction of the mean atherosclerotic lesion area in en face aortas; (2) decrease in total cholesterol (TC) and very low density lipoprotein cholesterol plus low density lipoprotein cholesterol (VLDLc+LDLc) levels; (3) increase in PPAR $\alpha$ mRNA and RCT; (4) decrease in SREBP-1c; (5) induction of CPT-1 mRNA, SOD1 and SOD2, Gpx3 mRNA, LDL receptor mRNA and protein levels; and (6) inhibition of the foam cell formation. HLF also protected rats against diabetic cardiomyopathy and the mechanism may be involved in reducing oxidative stress and inflammation via inactivation of the $\mathrm{PKC}-\alpha$ signaling pathway (Min et al., 2017).

The new norditerpenoids (Table 2) isolated from the leaves of $C$. pinnatifida exhibited exceptionally potent antithrombotic activities in vitro and in vivo, pinnatifidanoside $\mathrm{F}$ being the most potent one (Gao et al., 2017). It inhibited ADP induced platelet aggregation, which is mediated through the response to the specific receptor of $\mathrm{P} 2 \mathrm{Y}(12)$, and prolonged the time to form thrombocytes induced by $\mathrm{FeCl}_{3}$ in the caudal vessels of zebrafish. In vivo study with diabetic rats demonstrated that resistance training and $C$. oxyacantha extract can synergistically decrease ischemia-reperfusion injury by oxidative stress reduction: injury indices (plasma lactate dehydrogenase, creatine kinase myocardial band isoenzyme and infarction size) were significantly lower after sedentary diabetic group treatment with extract, whereas glutathione peroxidase and myeloperoxidase levels after reperfusion increased and decreased, respectively, in response to training and $C$. oxyacantha (Ranjbar et al., 2018). On the other hand, the study with 116 patients who underwent cardiac surgery showed that those who recently consumed 
hawthorn extract had a significantly higher rate of postoperative bleeding and overall mortality rate, which indicates that hawthorn extract consumption increases the potential for bleeding and the amount of chest tube output after cardiac surgery (Rababa'h et al., 2016).

C. oxyacantha alcoholic extract produced an antiarrhythmic effect that was induced by digoxin in Wistar rats; however, in the clinical use of this extract, the hypotensive effect should be considered (Alp et al., 2015). Another in vivo study reported that administration of methanolic C. songarica extract at the dose of $300 \mathrm{mg} / \mathrm{kg}$ body weight to albino rats with $\mathrm{CCl}_{4}$-iduced toxicity significantly decreased serum creatinine, urea, and cholesterol, malondialdehyde (MDA) in kidney and heart tissues, along with recovery in antioxidant enzyme levels (Ganie et al., 2016). It was also reported that standardized Crataegus extract prevented DOCA-salt-induced hypertension and alteration of cardiac, vascular and renal structure and function in rats (Schini-Kerth et al., 2015). One of the main hawthorn bioactives vitexin inhibited cytochrome P450 enzyme (CYP3A1) in a concentration-dependent and time-dependent manner while CYP2C11 enzyme activity was induced after short period treatment but inhibited after long period treatment. It was concluded that vitexin can either inhibit or induce the activities of these enzymes and possible herb-drug interactions should be considered when vitexin is co-administered with some CYP2C11 or CYP3A1 substrates in clinic (Wang et al., 2015).

Some studies reported antithrombotic and anti-vasoconstriction effects exerted by Crataegus bioactives. Thus, among 15 from C. pinnatifida leaves isolated compounds (Table 2) (65,7Z,9R)roseoside, eriodectyol and 2 "-O-rhamnosyl vitexin exerted potent antithrombotic activity in vitro, which was in agreement with the in vivo results obtained in transgenic zebrafish system ( $\mathrm{Li}$ et al., 2015). C. monogyna and C. davisii significantly inhibited the carrageenan-induced mouse tail thrombosis and may potentially be used as therapeutic agents or complementary treatments against thrombosis (Arslan et al., 2015). Euscaphic acid isolated from the crude ethyl acetate extract of $C$. azarolus var. aronia showed high anti-vasoconstriction effects on aortic rings, supporting the use of this medicinal plant in cardiovascular disease (Mahmud et al., 2016).

\section{Hypolipidemic and hypoglycemic activity}

\subsection{Hypolipidemic effects}

Lipid-lowering effects of hawthorn have been widely studied in vivo in many cases using HFD animals. Plant preparations demonstrated the ability to lower tricylglycerol (TG), total cholesterol (TC), LDLC and VLDLC, and to increase HDLC in plasma and these effects have been explained by several possible mechanisms (Yang and Liu, 2012). Recently published articles extended existing knowledge on hypolipidemic benefits of Crataegus preparations, particularly HLF, some of them carried out in in vivo studies with NAFLD animals and reported beneficial effects on liver health, which highly depends on HFD.

C. pinnatifida extract decreased the levels of serum TC, LDLC, hepatic TG and MDA, increased mRNA expression of nuclear erythroid 2-related factor (Nrf2), heme oxygenase-1 (HO-1), Gpx and reversed the suppression of protein levels in ovariectomized rats (Yoo et al., 2016). Li et al. (2015) reported that $C$. pinnatifida HLF ameliorated hepatic steatosis by enhancing the adiponectin/ AMPK pathway in the liver of HFD-induced NAFLD rats. Several beneficial events were determined: (1) lowering body and liver weight and liver/body weight ratio; (2) improving serum parameters and liver dysfunction; (3) decreasing hepatic lipid accumulation; (4) increasing circulating adiponectin levels and up-regulating the expression of adiponectin receptors (AdipoR2) in the liver; and (5) activating AMP-activated protein kinase (AMPK) and altering AMPK-mediated SREBP-1c, PPAR- $\alpha$ and their downstream targets (Li et al., 2015). The inhibitory activities of $C$. pinnatifida extract isolated with $50 \%$ ethanol were more effective against formation of advanced glycation end products (AGEs) and $\alpha$-glucosidase, while water extract better inhibited aldose reductase (Kang, 2015).

Investigation of the effects of aqueous extract of $C$. aronia (syn. azarolus L.) on sperm parameter and testicular structure in control and NAFLD-induced rats showed the improvements of the following indicators: (1) lower hepatic TG and cholesterol contents; (2) higher levels of testosterone, luteinizing hormone and follicle-stimulating hormone; (3) increased epididymis weight, sperm count and motility; and (4) increased testicular levels of glutathione, higher protein levels of Nrf2, $\gamma$-glutamylcysteine synthetase and SOD (Dallak, 2018).

The potential of novel multi-targeted herbal formula containing Crataegus Fructus, sylimarin, Schisandrae Fructus and Momordica charantia, as a therapeutic agent for diet-induced metabolic syndrome with special emphasis on NAFLD, dyslipidemia and type 2 diabetes, was studied using male C57B1/6 mice. Crataegus Fructus aqueous extract inhibited differentiation of 3T3-L1 preadipocytes and cholesterol uptake into Caco-2 cells, while the whole herbal formula exhibited mitigation of diet-induced increase of various indicators in vivo, namely (1) a trend to reduce body weight and fat pad mass, (2) significant reduction in liver weight, liver lipid, and plasma lipid, (3) reduction of liver inflammation, and (4) improvement of adiponectin level (Elaine et al., 2018).

The results of a number of studies support the hypothesis that hawthorn possesses both therapeutic and protective effect for NAFLD. C. aronia extract and simvastatin significantly reduced lipids and thiobarbituric acid reactive substances (TBARS), which were increased by oxidative stress in HFD rat group, and treated damage to hepatic cells, while only the extract induced GSH. $C$. aronia and simvastatin treatments differentially reversed hepatic injuries (Al Humayed et al., 2017). Another in vivo study demonstrated that $C$. aronia significantly reduced liver index $(3.85 \%$ versus $6.22 \%$ in HFD rat group), increased HDLC/LDLC and improved oxidative stress biomarker and enzymes indicating liver damage (Al Humayed, 2017). Ethanol extract of C. oxyacantha administered at 10 and $20 \mathrm{mg} / \mathrm{kg}$ to HFD rats reduced the level of some liver biomarkers, especially lactate dehydrogenase (LDH), increased GSH and FRAP and decreased lipid peroxidation, which may be beneficial in restoring the hepatocyte damage (Saeedi et al., 2018).

Polyphenols-enriched extracts from hawthorn fruit peels (HPP) and flesh (HFP), containing chlorogenic acid, epicatechin, rutin and hyperoside as the main polyphenolic constituents (HPP > HFP), reduced alanine aminotransferase (ALT), aspartate aminotransferase (AST) and alkaline phosphatase (ALP) activities, as well as the ratio of pro-apoptotic protein with B-cell lymphoma-2 (Bax/Bcl-2) in mice with liver injury, which was induced by a high-fructose diet. HPP was more effective than HFP in mitigating liver inflammation and oxidative stress by inhibiting inflammatory cytokine (TNF- $\alpha$, IL-1 and IL-6) release, elevating antioxidant enzyme activities and PPAR $\alpha$ expression, reducing Nrf-2 and antioxidant response element (ARE) expression in mice. HPPtreated mice also had lower levels of TC, TG, LDLC, VLDLC and apoprotein B (Apo-B), and higher levels of HDLC and Apo-A1 than HFP-treated mice due to reduced expression of fatty acid syn- 
thetase (FAS) (Han et al., 2016b).

Hypolipidemic and antioxidant effects of aqueous and ethanolic extracts of $C$. pinnatifida fruits were compared in hyperlipidemia rats and obvious differences between extracts were observed, probably due to the existing differences in the content of phenols (Shao et al., 2016). Polyphenolic extracts of C. azarolus and C. monogyna leaves, fruit peel, and pulp, possessing antioxidant activity, protected against thermal-cholesterol degradation while pre-treatment with the extracts preserved liposomes and rat liver-homogenate from oxidative $\mathrm{Cu}^{2+}$ and $\mathrm{Fe}^{2+}$ induced damage (Belkhir et al., 2016). Synergic effects and potential mechanisms of action of Astragalus polysaccharides combined with Crataegus flavonoids were studied with diabetic mice. The mixture significantly reduced the fasting blood glucose, food and water intake and restored increased serum insulin levels and islet cell function; it also increased protein expression levels of pancreatic and duodenal homeobox-1 and phosphorylated AMPK in the pancreatic and liver tissue samples, respectively. The mixture significantly increased the mRNA expression levels of neurogenin 3 (v-maf musculoaponeurotic fibrosarcoma oncogene), protein A and insulin, and simultaneously decreased the expressions of IL6, TNF- $\alpha$ and chemokine (C-C motif) ligand 2 in the pancreatic islet cells of diabetic mice (Cui et al., 2016).

One of the most important Crataegus phytochemical, hyperoside, induced apoptosis in human hepatic stellate LX-2 cells and decreased the levels of $\alpha$-smooth muscle actin ( $\alpha$-SMA), type I collagen, and intracellular ROS. Remarkably, hyperoside also inhibited the DNA-binding activity of the transcription factor NF- $\kappa \mathrm{B}$ and altered expression levels of NF- $\mathrm{kB}$-regulated genes related to apoptosis, including pro-apoptotic genes Bcl-Xs, DR4, Fas, and FasL and anti-apoptotic genes A20, c-IAP1, Bcl-X-L and RIP1. These results suggest that hyperoside may have potential as a therapeutic agent for the treatment of liver fibrosis (Wang et al., 2016).

\subsection{Hypoglycemic effects}

Enzyme inhibitory activity in vitro is a simple and widely used method for the preliminary evaluation of hypoglycemic effects. Comparison of hawthorn extracts prepared from plant fruit using $80 \%$ ethanol, $80 \%$ methanol, $80 \%$ acetone and pure water revealed that acetone extract had the highest $\alpha$-glucosidase inhibitory activity while the highest $\mathrm{DPPH}^{\bullet}$ scavenging capacity and FRAP was exhibited by the water extract. Polyphenols, triterpenoids, protocatechuic acid and epicatechin contributed to the $\alpha$-glucosidase inhibitory activity, while flavonoids, polyphenols, vanillic acid, gallic acid, catechin and chlorogenic acid contributed to the antioxidant activity (Miao et al., 2016).

Antihyperglycemic (Male albino mice) and antihyperlipidemic (Sprague Dawley rats) activities of the ethanolic extract of $C$. azarolus var. eu-azarolus leaves and the isolated $3 \beta-\mathrm{O}$ acetyl ursolic acid were proved by significantly reduced mice blood glucose level in a time-and dose-dependent manner, while ethanolic extract significantly reduced LDLC, VLDLC, TC and TG and increased HDLC. In addition, ethanolic extract and $3 \beta-O$ acetyl ursolic acid reduced the activity of pancreatic lipase in vitro (Abu-Gharbieh and Shehab, 2017). C. aronia significantly improved the oral glucose tolerance test, lowered plasma glucose, serum lipid levels and the hepatic glycogen content. In addition, it significantly lowered the levels of hepatic lipid peroxidation, TNF- $\alpha$ and IL-6, while the level of reduced glutathione (GSII) was enhanced and SOD activity was increased (Mostafa et al., 2018). Regarding the mechanism involved, it enhanced hepatic mRNA expression of the insulin receptor A isoform (IR-A) and glucose 6-phosphatase (G6Pase), while the expression of glucose transporter-2 (GLUT-2) and glycerol kinase (GK) mRNA was lowered. Consequently, C. aronia ameliorated type 2 diabetes mellitus by inhibiting hepatic glucose output. Out of six tested plants, ethanolic extract of C. monogyna leaves exhibited the best $\alpha$-glucosidase inhibition activity with $\mathrm{IC}_{50}=10.39 \mu \mathrm{g} / \mathrm{mL}$, and was stronger inhibitor of $\alpha$-amylase and $\alpha$-glucosidase than its traditionally made with hot water tea (Sayin et al., 2018).

Complex herbal formulas with Crataegus have also been tested. The potential anti-obesity effects (inhibition of lipogenesis and adipogenesis) of HT048 (a combination of $C$. pinnatifida leaf and Citrus unshiu peel extracts) was investigated in vitro and in vivo using 3T3-L1 adipocytes and male Sprague Dawley rats, respectively (Lee et al., 2015). HT048 suppressed, dose-dependently, adipocyte differentiation and stimulated glycerol release and decreased the expressions of PPAR and C/EBP mRNA in adipocytes while in rats it significantly reduced the body and fat, as well as serum lipid levels, decreased expression of the hepatic lipogenesis-related genes and increased the expression of the oxidation-related genes (Lee et al., 2015). The effects were supported one year later when it was demonstrated that HT048 decreased body and total white adipose tissue weight and serum insulin levels in HFD-fed obese rats, whereas at the molecular level the supplement downregulated genes involved in lipogenesis, gluconeogenesis, and adipogenesis, and up-regulated $\beta$-oxidation genes. In addition, no interactions were observed between HT048 supplementation and orlistat drug, which was also used in the study (Lee et al., 2016). Orlistat and $C$. monogyna ethanolic extracts significantly lowered the hypercholesterolemia-increased serum level of hepatic enzymes and lipid peroxidation level in the hypercholesterolemia-induced oxidative stress in rats, protected from hepatic thiol depletion, and improved lipid profile and hepatic damages (Rezaei-Golmisheh et al., 2015). The results of Cheng et al. (2015) study with mice demonstrated that supplementation with a formula composed of Rhizoma dioscorea, Lycium barbarum, Prunella vulgaris and hawthorn may be a potent alternative as an anti-diabetic health-promoting diet. Finally, hawthorn pectin pentasaccharide (HPPS) was shown to be more effective than pectin (HP) and pectin hydrolyzates (HPH) in decreasing the body weight gain, liver weight, and plasma and hepatic TC of hamsters fed by high-cholesterol diets. However, the HP group had higher cholesterol excretion capacities than the HPH and HPPS groups by inhibiting cholesterol absorption in the diet (Zhu et al., 2015a). Thus, HPPS could be a promising antiatherogenic dietary ingredient for the development of functional food to improve cholesterol metabolism.

\section{Anticancer effects}

The majority of studies evaluating anticarcinogenic properties of plant origin products are based on cell cytotoxicity and apoptosis assays, while in vivo studies, which provide more relevant physiologically information, are rather scarce. In addition, the mechanism of activity is very important issue in evaluating anticancer properties. Several recent studies, which were focusing on anticancer effects of Crataegus extracts, their fractions and purified compounds, are reviewed in this section.

Hawthorn's health benefits are mainly associated with the high contents of polyphenolics. C. pinnatifida var. major fruits, containing high amounts of flavonoids and triterpenoids, showed potent antiproliferative effect against human cancer cells lines (liver, Hep G2; breast, MCF-7 and MDA-MB-231); particularly strong activity was determined for triterpenoids-enriched fraction and its main 
ingredient ursolic acid, which induced restriction point G1 arrest, downregulated proliferating cell nuclear antigen (PCNA), cyclindependent kinase (CDK4), and a protein Cyclin D1 (in humans encoded by the CCND1 gene) and upregulated cyclin-dependent kinase inhibitor 1p21(Waf1/Cip1) in MDA-MB-231 cells (Wen et al., 2017). In addition, the supplements induced MDA-MB-231 apoptosis via mitochondrial death pathway induced by caspase ( 9 and 3 ) activation.

The studies performed by Mustapha et al. (2015, 2016a, b, c) demonstrated various effects of $C$. azarolus ethyl acetate extract as well as isolated from it hyperoside and vitexin-2"-O-rhamnoside. The extract and vitexin rhamnoside exhibited anti-proliferative activity against B16F10 melanoma cells and the ability to reduce melanin content by inhibiting the tyrosinase activities (Mustapha et al., 2015); it also demonstrated significant cellular antioxidant capacity against the ROS in B16F10 and primary human keratinocyte cells (Mustapha et al., 2016b). In addition, total oligomeric flavonoids extract (150 mg/kg body weight, 21 days) significantly inhibited tumor growth volume and weight in Balb/c mice inoculated with B16F10 cells and therefore was suggested as a new candidate for skin care products (Mustapha et al., 2016b). The extract and hyperoside also exhibited an immunomodulatory effect by modulating macrophage lysosomal enzyme activity and NO release in mice and anti-inflammatory activity, which was concomitant with the cellular antioxidant effect against macrophages and solenocytes (Mustapha et al., 2016a). Extract-induced growth inhibitory effect in human colorectal cancer cell lines HCT-116 and HT-29 was associated with DNA fragmentation, sub-G1 peak, loss of mitochondrial potential, and poly (ADP-ribose) polymerase (PARP) cleavage. The extract also induced the cleavage of caspase- 8 and had no effect on steady-state levels of total Bcl-2 protein, whereas Bax levels decreased significantly in a dose-dependent manner in both tested cell lines (Mustapha et al., 2016b). It may also be mentioned that in searching of relatively mild and safe tyrosinase inhibitors, one of six isolated from $C$. pinnatifida seeds 8-0-4' neolignans, demonstrated promising tyrosinase-inhibiting and good antioxidant activities (Huang et al., 2015b).

Two other studies also investigated the effects of hyperoside. It was suggested as a candidate of concomitant treatment for leukemia due to the ability to potentiate $\mathrm{As}_{2} \mathrm{O}_{3}$-dependent apoptosis of HL-60 human acute myeloid leukemia cells by upregulating LC-II and inducing autophagy effects (Zhang et al., 2015). In addition, hyperoside inhibited Bcl-2-associated agonist of cell death BAD from phosphorylating, reactivated caspase- 9 , and increased cell cycle regulating protein p27 levels. In another study, hyperoside dose-dependently $(0.5,1,2 \mathrm{mmol} / \mathrm{L})$ increased the expression of LC3-II and autophagosome numbers in human non-small cell lung cancer cell line A549 cells; however, such effects in human bronchial epithelial cell line BEAS-2B cells were not observed. Moreover, hyperoside inhibited the phosphorylation of Akt, mTOR, p70S6K and 4E-BP1, but increased the phosphorylation of ERK1/2 in A549 cells (Fu et al., 2016).

The extract from hawthorn fruit peel (EPHF), rich in phenolic compounds, exhibited dose-dependent cytotoxicity on MCF-7 and SKOV-3 human tumor cell lines with the $\mathrm{IC}_{50}$ of 2.76 and 80.11 $\mu \mathrm{g} / \mathrm{mL}$, respectively (Wu et al., 2017). Polyphenolic extracts of C. azarolus and C. monogyna leaves, fruit peel, and pulp $(0.24$ $4.8 \mathrm{mg} / \mathrm{mL}$ ) were cytotoxic to cancer Caco-2 cells, at the same time being nontoxic for differentiated Caco-2 cells (Belkhir et al., 2016). Ethanolic extract of C. microphylla flowers and leaf buds demonstrated cytotoxic and antiproliferative activity against $\mathrm{HeLa}$ cell $\left(\mathrm{IC}_{50}=0.871 \mathrm{mg} / \mathrm{mL}\right)$ and least cytotoxicity on normal human peripheral mononuclear cells (Bura et al., 2016). Methanol, ethanol and ethyl acetate extracts of $C$. songarica K. Koch exhib- ited potent in vitro anticancer activity on MCF-7, HeLa, HepG2, SF-295, SW480 and IMR-32 cancer cell lines with $\mathrm{IC}_{50}$ values of 28.57-85.106 $\mu \mathrm{g} / \mathrm{mL}$, while methanol extract demonstrated protective activity for albino rats' kidney and heart tissue against $\mathrm{CCl}_{4-}$ induced toxicity in vivo (Ganie et al., 2016). C. monogyna extract at $100-75 \mu \mathrm{g} / \mathrm{mL}$ concentrations exhibited better antiproliferative activity against $\mathrm{C} 6$ cell lines than 5-flurouracil drug (5-FU) and cisplatin, and also demonstrated considerable antiproliferative activity against HeLa cells (Yaglioglu et al., 2016). Ethanolic C. meyeri flower extracts, which contained flavonoids and procyanidins and had high in vitro antioxidant capacity in $\mathrm{DPPH}^{\circ}, \beta$-carotenelinoleic acid and TPC assays, also demonstrated antiproliferative activity against PC3 and PC14 cells and decreased the levels of serum alanine aminotransferase and aspartate aminotransferase in the blood of partially hepatectomized rats (Ozay et. al., 2015). Thus, the extracts were suggested as protective agents against partial hepatectomy-induced liver injury in rats and inhibitors of the proliferation of human non-small lung cancer cells.

Recently isolated from the fruit of $C$. pinnatifida phenylpropanoids crataegusoids (Table 2) were cytotoxic against human hepatocellular carcinoma cells HepG2 and Hep3B, while crataegusoids $\mathrm{C}$ and $\mathrm{D}$ with two methoxy groups at C-3' most remarkably induced apoptosis in HepG2 cells indicating on structure-activity relationships (Guo et al., 2018). Finally, the hydroxy-olean-12en-28-oic acid (HOA) triterpenoids from hawthorn berry, namely $3 \beta, 6 \beta, 18 \beta, 23$-tetraHOA, $2 \beta, 3 \beta, 6 \beta, 18 \beta$-tetraHOA and $2 \alpha, 3 \beta, 6$ $\beta, 18 \beta, 23$-pentaHOA were potent inhibitors of HepG2 and MCF-7 cells, with the $\mathrm{EC}_{50}$ values lower than $5 \mu \mathrm{M}$ (Qiao et al., 2015).

\section{Neuroprotective effects}

Neuroprotective effects of sesquineolignans (Table 2) isolated from the hydroethanolic (70\%) extract of $C$. pinnatifida var. $m a-$ jor seeds towards $\mathrm{H}_{2} \mathrm{O}_{2}$-induced damage in human neuroblastoma SH-SY5Y cells were recently reported by Huang et al. (2018a, b). All of these exhibited significant neuroprotective activity, compared with trolox, while 6 compounds demonstrated the survival rate of $90.74 \%$ at the $50 \mu \mathrm{M}$ concentration, by inhibiting cellular apoptosis determined by Hoechst 33258 staining and annexin V/ PI analysis (Huang et al., 2018a). Sesquineolignans also inhibited $\beta$-amyloid aggregation; ( $\left.7{ }^{\prime} S, 8^{\prime} R, 8 R\right)$-isolariciresinol-9'- $\beta-D$ glucopyranoside and lyoniside were stronger inhibitors of $A \beta_{1-42}$ aggregation than curcumin (Huang et al., 2018b). Possible mechanism of interactions was investigated by molecular docking.

The potential of hawthorn as natural antidepressant was also reported. The levels of typical markers of depression in animal models, monoamine oxidase B and reduced spine numbers along neuronal dendrites, were improved by chlorogenic acid or the extract of $C$. pinnatifida both in vivo using mice model with induced depression-like phenotypes by daily injection of stress hormone, and in vitro using cultured astrocyte type I clone C8-D1A cells (Lim et al., 2018). A protective effect of vitexin, which is one of the most important flavonoid in hawthorn leaves, against neurotoxicity has also been reported; however, the mechanisms of action remain elusive. Systemic vitexin treatment significantly reduced neurological deficit, cerebral infarct volume and neuronal damage when compared with the ischemia/reperfusion (I/R) injury mice. Vitexin markedly upregulated extracellular signal-regulated kinases (p-ERK1/2), downregulated c-Jun N-terminal kinases (p-INK) and p38 phosphorylation (p-p38), increased B-cell lymphoma 2 (Bcl-2) expression and suppressed the overexpression of Bax in the $\mathrm{I} / \mathrm{R}$ mice, thus, protecting brain against cerebral $\mathrm{I} / \mathrm{R}$ injury 
regulated by mitogen-activated protein kinase (MAPK) and apoptosis signaling pathways (Wang et al., 2015a). Vitexin presented no cytotoxicity in RAW 264.7 cells and effectively reduced leukocyte migration in vivo, TNF- $\alpha$, IL-1 $\beta$, PGE2 and NO releases and increased in IL-10 release in the LPS-challenged mice; it was also able to regulate transcriptional factors for pro-inflammatory mediators, by reducing the expression of p-p38, p-ERK1/2 and p-JNK (Rosa et al., 2016). Chen et al. (2016) also attempted to obtain evidence on mechanisms using Sprague Dawley rats and human PC12 pheochromocytoma neurosecretory cells with isoflurane-induced neurotoxicity and cytotoxicity, respectively, and suggested that vitexin mediates by targeting the transient receptor potential cation channel subfamily V member 1 gene (TRPV1) and N-methyl D-aspartate receptor subtype $2 \mathrm{~B}$ protein (NR2B) signaling pathways. The study of $\mathrm{Hu}$ et al. (2018) demonstrated that vitexin from $C$. pinnatifida protected dopaminergic neurons against methyl-4-phenylpyridine/1-methyl-4-phenyl-1,2,3,-6-tetrahydropyridine (MPP+/MPTP)-induced neurotoxicity through the activation of phosphatidylinositol-4,5-bisphosphate 3-kinase/ protein kinase $\mathrm{B}$ (PI3K/Akt) signaling pathway, and these findings may facilitate the clinical application of vitexin in the Parkinson's disease therapy.

The combination of Radix Puerariae and hawthorn fruit tested with diabetic rats showed the following effects: (1) reduced random blood glucose, TC, TG and improved glucose tolerance; (2) reversed the loss in body weights; (3) reduced depressive-like behavior as measured by open field, the elevated plus-maze, locomotor activity, and forced swimming tests; and (5) upregulated brain-derived neurotrophic factor and activated extracellular signal-regulated protein kinase (Luo et al., 2016). Vitexin exerted behaviorally-specific antinociceptive effect against postoperative pain using a mouse model with surgical incision on the right hindpaw, which was mediated through opioid and GABA(A) receptors (Zhu et al., 2019). It was observed that $C$. pinnatifida containing Naodesheng formula could reverse most of the cerebral ischemia reperfusion induced imbalanced metabolites in brain tissue, plasma and urine, which indicates on its protective effect on ischemic stroke rats by mechanisms involving multiple metabolic pathways, including energy metabolism, amino acid metabolism, oxidative stress and inflammatory injury (Luo et al., 2016). Most recently potential efficacy of Naodesheng for treating Alzheimer's disease was evaluated by combined machine learning, molecular docking, and pharmacophore mapping, and as a result constituent-target network, constituent-target-target network and target-biological pathway network was built for this formula as the virtual screening and network pharmacology method for the first time (Pang et al., 2018). C. oxyacantha extract ameliorated some seizure parameters in penicillin-induced epilepsy in gerbils; however, further and more advanced physiologic and neurochemical studies are required to determine the mechanisms involved (Cakir et al., 2016).

The compounds from $C$. oxyacantha effectively inhibited $\mathrm{AChE}$, from $\mathrm{IC}_{50}=5.22 \mu \mathrm{M}$ ( $\beta$-sitosterol-3-O- $\beta$-D-glucopyranoside $)$ to $44.47 \mu \mathrm{M}$, and $\mathrm{BChE}$ activity with $\mathrm{IC}_{50}=0.55-15.36 \mu \mathrm{M}$. In addition, docking procedures with Genetic Optimization for Ligand Docking suit v5.4.1 were applied to study the inhibition mechanism, while software admetSAR predicted that both of the isolated compounds can cross blood brain barrier (BBB+) (Ali et al., 2017). $\mathrm{AChE}$ catalyzes the breakdown of acetylcholine and of some other choline esters that function as neurotransmitters, while $\mathrm{BChE}$ in plasma can be used as a liver function test in both hypercholinesterasemia and hypocholinesterasemia. Potential antioxidant, hypoglycemic, and neuroprotective effects of acidified methanol or ethanol extracts of C. microphylla stem barks and leaves were supported by evaluating their AChE, tyrosinase and $\alpha$-glucosidase inhibitory, $\mathrm{DPPH}^{\bullet}$ scavenging capacity and protective activity against hydroxyl radicals-induced DNA strand scission (Renda et al., 2018). Macroporous resin Diaion HP-20 adsorption chromatography was applied to obtain rich in phenolics extract from hawthorn fruit peel (EPHF), which contained ideain, epicatechin and chlorogenic acid as the main constituents (179.4, 40.9, and $10.0 \mathrm{mg} / \mathrm{g}$, respectively) and exhibited strong antioxidant (ORAC $=11.65 \mu \mathrm{M} \mathrm{TE} / \mathrm{mg}, \mathrm{IC}_{50}$ in DPPH${ }^{*}$ scavenging $\left.=6.72 \mu \mathrm{g} / \mathrm{mL}\right)$ and AChE inhibitory $\left(\mathrm{IC}_{50}=11.72 \mu \mathrm{g} / \mathrm{mL}\right.$ ) activities (Wu et al., 2017). Methanolic extract of $C$. microphylla was shown as a good source of antioxidant, antimicrobial, antidiabetic, anticholinesterase, and anticancer agents in various in vitro assays (Aksoy-Sagirli at al., 2017).

\section{Skin protective and other health effects}

The extract from the Greek hawthorn C. pycnoloba was tested as a potent inhibitor of melanin synthesis during early zebrafish embryo development. The activity based subfractionation enabled to identify 3 melanogenesis inhibiting dibenzofurans (Table 2), acting not via inhibition of tyrosinase or interfering with neural crest differentiation or migration, but via binding to the aryl hydrocarbon receptor by activating its signaling pathway and causing the induction of the target genes expression (Agalou et al., 2018). Ursolic aldehyde, isolated from the active fragments of C. pycnoloba, had no melanin synthesis inhibition activity. The assays with HaCaT human keratinocytes, normal human dermal fibroblasts (HDFs), and mice showed that hawthorn polyphenol extract (HPE), containing chlorogenic acid, procyanidin B2, and epicatechin (13.5, 19.2 , and $18.8 \%$ of the TPC, respectively), can prevent UVB radiation-induced skin photo-aging by promoting human cell proliferation in vitro and regulating matrix metallopeptidase expression and type I procollagen production in vivo (Liu et al., 2018). Ethanol extract from $C$. pinnatifida fruits $(\mathrm{TPC}=61.31 \mathrm{mg} / \mathrm{g}, \mathrm{TFC}=25.42$ $\mathrm{mg} / \mathrm{g}$ ) at $50 \mu \mathrm{g} / \mathrm{mL}$ reduced melanin contents by $8.5 \%$ while at $1,000 \mu \mathrm{g} / \mathrm{mL}$ reduced intracellular tyrosinase activity by $46.83 \%$, thus suggesting that the extract could be used as a whitening agent in cosmetics (Park et al., 2017a). The mixture of $P$. ginseng and C. pinnatifida improved procollagen type I expression, diminished matrix metalloproteinase-1 secretion and improved various other human skin values associated with aging, wrinkle formation and moisture (Hwang et al., 2017). Creams with $5-15 \%$ of $C$. pontica leaf extract have a healing effect on dermal toxicity caused by T-2 toxin as it was shown by the study with Iranian rabbits (Kalantari et al., 2016). The penetration of active substances into the full undamaged human skin from the semisolid preparations containing C. oxyacantha extract was evaluated ex vivo. However, it was observed that, although the extract exhibited antimicrobial and antiradical activity, its compounds stay on the surface of the undamaged human skin, thus only traces of hyperoside and isoquercitrin were found in the epidermis (Stelmakienè et al., 2016).

The effects of $C$. orientalis M Bieber extract on serum oxidative status and alveolar bone loss in experimental periodontitis was studied in vivo and showed inhibitory effect on periodontal inflammation and alveolar bone loss by regulating total antioxidant (TAS)/oxidant (TOS) status and oxidative stress index levels in periodontal disease in rats when administered systemically (Hatipoglu et al., 2015). C. azarolus extract was active against herpes simplex virus-1 (HSV-1), and antiviral activity correlated with TPC $(\mathrm{R}=0.773, \mathrm{p}<0.001)$ and free radical scavenging capacity $(\mathrm{R}=-0.684, \mathrm{p}<0.01)$ (Moradi et al., 2018). Hawthorn hyperoside $(10,50,100 \mu \mathrm{mol} / \mathrm{L})$ dose-dependently inhibited LPS-induced pro- 
liferation and migration of human rheumatoid fibroblast-like synoviocytes (RA FLSs) in vitro. Furthermore, hyperoside decreased LPS-stimulated production of TNF- $\alpha$, IL-6, IL-1 and MMP-9 in the cells, inhibited LPS-induced phosphorylation of $\mathrm{p} 65$ and $\mathrm{I} \kappa \mathrm{B} \alpha$, and suppressed nuclear translocation of p65 and DNA biding of $\mathrm{NF}-\mathrm{\kappa B}$ in the cells. Three-week administration of hyperoside significantly decreased the clinical scores, and alleviated synovial hyperplasia, inflammatory cell infiltration and cartilage damage on mouse with collagen-induced arthritis. Hyperoside inhibited LPS-induced proliferation, migration and inflammatory responses in RA FLSs in vitro by suppressing activation of the NF- $\kappa$ B signaling pathway, which contributes to the therapeutic effects observed in mice with collagen-induced arthritis (Jin et al., 2016).

In the study with male Sprague-Dawley rats hydroalcoholic extract of C. azarolus ssp. aronia fruit significantly lowered systolic blood pressure and phenylephrine maximal response and increased acetylcholine maximal response, serum SOD, and serum glutathione reductase in the renal artery-clipped group receiving vehicle. It was concluded that antihypertensive effects of extract may be partly due to antioxidant and NO releasing effects (Haydari et al., 2017). Ethyl acetate fraction of $C$. dahurica methanol extract demonstrated the greatest antioxidant activity while n-butanol fraction significantly accelerated the gastrointestinal transit in mice. Thus, this plant was suggested to serve as a good source of antioxidants and digestion-improving agents (Wang et al., 2018). Ethanolic extracts of $C$. orientalis leaves and berries inhibited cyclooxygenase-1 (COX-1) and 12-lipoxygenase (12-LOX), while its leaf extract showed a concentration dependent inhibition of COX-1 pathway products, 12-HHT and TXB2 (Šavikin et al., 2017).

Rhodiolae Kirliowii Radix et Rhizoma and C. pinnatifida Fructus may provide sources of potential antiviral compounds that was evidenced by hemagglutination inhibition activity on B human polyomaviruses BK KPyV and JCPyV VLPs and reducing their expression in infected cells (Chen et al., 2017). C. oxycantha buds fluid extract and the hydro-ethanolic macerate were active against thirty-due clinical strains of $U$. urealyticum, with MIC ranges of $15.6-250$ and $15.6-62.5 \mu \mathrm{g} / \mathrm{mL}$, respectively. Meanwhile, among the major purified flavonoids luteolin 3,7-diglucoside and apigenin-7-O-glucoside were the most active compounds with MICs $0.48-1.95$ and $0.48-3.9 \mu \mathrm{g} / \mathrm{mL}$, respectively (Bisignano et al., 2016). Ethanolic extract of C. azarolus var. eu-azarolus Maire leaves and its hexane, chloroform, and n-butanol fractions as well as ursolic acid, $3 \beta-O$-acetyl ursolic acid and quercetin 3-O-methyl ether showed variable antimicrobial activities against $E$. coli, $P$. aeruginosa, S. aureus, and C. albicans (Abu-Gharbieh and Shehab, 2017).

\section{Toxicity of hawthorn preparations}

Safety of Crataegus preparations has been proven by many studies and safe history of use. Some recent studies with $C$. oxyacantha extend the knowledge on this issue. Evaluation of $C$. oxyacantha fruit extract showed that it did not produce marked genotoxic effects at concentrations of 2.5 or $5 \mu \mathrm{g} / \mathrm{mL}$ in leukocytes and human liver hepatocellular carcinoma HepG2 cultured cells; however, at concentrations of $10 \mu \mathrm{g} / \mathrm{mL}$ or higher significant DNA damage and clastogenic/aneugenic responses were observed. The extract induced mutagenic effects in TA98 strain of S. typhimurium (Ames test) with metabolic activation at all tested concentrations (2.5 to $500 \mu \mathrm{g} / \mathrm{mL}$ ). Consequently, under certain experimental conditions, the extract exerts genotoxic and clastogenic/aneugenic effects in human cells, and mutagenicity in bacterial cells (De Quadros et al., 2017). Previous in vitro findings were also confirmed by the study of Yonekubo et al. (2018) with C. oxyacantha extract, showing that in comet assay it did not markedly induce DNA damage in leukocytes and bone marrow cells; however, in the micronucleus test the extract produced a significant rise in micronucleated polychromatic erythrocytes (PCE) in a non-dose dependent manner. The PCE/ normochromatic erythrocytes (NCE) ratio indicated no significant cytotoxicity under applied experimental conditions, however, $C$. oxyacantha fruits extract exhibited weak clastogenic and/or aneugenic effects in bone marrow cells of male mice (Yonekubo et al., 2018). It suggests that prolonged or high dose use of such extracts needs to be undertaken with caution. Most recently, the electrocardiographic effects of hawthorn in healthy adult volunteers was tested and it was concluded that a single dose of oral C. oxyacantha had no effect on electrocardiographic parameters in healthy volunteers (Trexler et al., 2018).

\section{Processing, quality control and other uses}

Raw plant material and natural products should be carefully prepared, considering various aspects, e.g. protection of sensitive active ingredients, convenient forms for dosing and administration, standardization in terms of concentration of active ingredients and others. Some recent studies have focused on such issues.

Drying is an important process for many natural ingredients for medicines and food supplements. Aral and Bese (2016) investigated convection-drying of Crataegus spp. fruit at 50, $6070{ }^{\circ} \mathrm{C}$ with air velocities of $0.5,0.9$ and $1.3 \mathrm{~m} / \mathrm{s}$ and applied different mathematical models for the experimental data. They observed that while the shrinkage decreased, the rehydration ratio increased with increasing air temperature and air velocity. Microwave-drying, oven-drying at 50 and $70{ }^{\circ} \mathrm{C}$, sun-drying and shade-drying were compared for the fresh fruits of $C$. azarolus and C. orientalis. The results showed that antioxidant capacity increased, and at the same time the TPC decreased with the temperature increase in oven drying, whereas in other drying methods (microwave, sun and shade-drying) the TPC increased; meanwhile, vitamin C content decreased in all samples. The samples dried in a microwave appeared to have the highest antioxidant capacity and it was concluded that it was the best method for preserving bioactive phytochemicals (Saadatian et al., 2016). Freeze-drying was reported to be better than hot air drying for hawthorn $(C$. pinnatifida) in terms of antioxidant, $\alpha$-glucosidase inhibitory potential, the TPC/TFC values and color (Kwon, 2016).

Immersing of hawthorn fruits in a glycine betaine solution for $15 \mathrm{~min}$ at $20{ }^{\circ} \mathrm{C}$ effectively prevented fruit chilling injury and improved nutritional characteristics at low-temperature storage (Razayi et al., 2018). It significantly delayed fruit pitting development during storage at $1{ }^{\circ} \mathrm{C}$ for 20 days, increased accumulation of glycine betaine, proline, phenols, flavonoids, anthocyanins, and ascorbic acid, which was concurrent with higher SOD, catalase (CAT), ascorbate peroxidase (APX), and $\mathrm{DPPH}^{\circ}$ scavenging capacity.

Emulsions prepared from the extracted from hawthorn pectin and candelilla wax were used as an edible film for treating Pleurotus ostreatus mushroom. This process reduced weight loss, improved firmness, and lightness, compared to untreated mushroom slices during 20 days of storage at $4{ }^{\circ} \mathrm{C}$ (Lozano-Grande et al., 2016). The functional $\mathrm{Ag}-\mathrm{Fe}_{3} \mathrm{O}_{4}$ nanocomposites, which were prepared via one-pot hydrothermal method using aqueous extract of $C$. pinnatifida leaves as reducing and capping agent, exhibited 
sustainable antibacterial activity against $S$. aureus and E. coli. The nanocomposites can be easily separated from the medium by a magnet and continues to exhibit recyclable antibacterial activity (Li and Yang, 2016). Tonic wine was produced by maceration of hawthorn fruits in red wine; as a result its TPC and antioxidant capacity remarkably increased (Muresan et al., 2016). Effects of 2,4-dichlorophenoxyacetic acid (2,4-D) combined to 6-benzylaminopurine (BAP) on callus induction, TPC and ascorbic acid production, as well as antioxidant activities in C. azarolus L. var. aronia leaf tissue cultures were assessed and it was found that the use of high level of 2,4-D over BAP could enhance the quality even more than the quantity of bioactive compounds in hawthorn leaf callus (Chaabani et al., 2015). The microcapsules containing $751 \mathrm{mg} / \mathrm{g}$ of C. monogyna bark procyanidins, mainly (-)-epicatechin, dimer B2, and trimer $\mathrm{C} 1$, were produced by spray drying using inulin and maltodextrin as encapsulants (Wyspiańska et al., 2017). The addition of C. monogyna phenolic-rich extracts significantly improved the oxidative stability of cooked pork patties as measured by TBARS and hexanal production, and the degree of consumer satisfaction regarding product's odor perception (Akcan et al, 2017). Ethanolic extract of C. monogyna berry was more effective than synthetic antioxidant BHA in reducing lipid oxidation and protein degradation, as well as for maintaining firmness and consistency of minced pork during 6 days of refrigeration at $4{ }^{\circ} \mathrm{C}$ (Papuc et al., 2018).

For quality control purposes, HPLC analysis was established for chlorogenic acid and hyperoside, which are among the major compounds in Crataegi fructus; the average contents (w/w \%) of these compounds in the 31 batches of products from Korea and China were 0.0438 and $0.0416 \%$, and 0.0399 and $0.0325 \%$, respectively (Wen et al., 2016). An accurate and advanced method has been established for the simultaneous determination of chlorogenic acid, vitexin and its $4 "-O$-glucoside, 2"-O-rhamnoside, orientoside, rutin and hyperoside in C. pinnatifida leaves. Under optimized conditions the yields of these phytochemicals were 0.46 , $0.30,0.38,4.37,0.033,0.036$, and $1.19 \mathrm{mg} / \mathrm{g}$, respectively, while $\mathrm{DPPH}^{\circ}$ and $\mathrm{ABTS}^{\cdot+}$ scavenging and reducing power of extract were $0.69 \mathrm{mg} / \mathrm{mL}\left(\mathrm{IC}_{50}\right), 0.86 \mathrm{mM} \mathrm{TE}$, and $0.24 \mathrm{mg} / \mathrm{mL}\left(\mathrm{IC}_{50}\right)$, respectively (Luo et al., 2015). A simple, sensitive liquid chromatography-tandem mass spectrometry (LC-MS/MS) method, which may serve for evaluating the pharmacokinetics, was developed and fully validated for the simultaneous determination of rutin, vitexin and its glycosides, hyperoside, shanyenoside in rat plasma after intravenous administration of hawthorn leaves flavonoids using lysionotin as an internal standard (Zhu et al., 2015).]

\section{Conclusion}

This review clearly shows that hawthorns remain an interesting and important topic both from the scientific investigation and practical application points of view. Recent studies of Crataegus spp. were focused on various aspects, including phytochemical characterization of different plant anatomical parts and drug forms, variations of bioactive compounds and antioxidant activities between plant species and cultivars from different origins, health benefits and some analytical, quality control and processing issues. Identification of new bioactive phytochemicals, particularly those belonging to non-phenolic structures, as well as intensive attempts for explaining the mechanisms in the treatment of various diseases and disorders with hawthorn preparations, extracts, separated fractions and purified compounds may be recognized as important required studies that would significantly complement the existing knowledge on Crataegus spp. in particular and natural products in general. In addition, the findings of recent years provide new ideas and suggest the trends for further studies of Crataegus spp.

\section{References}

Abuashwashi, M.A., Palomino, O.M., and Gómez-Serranillos, M.P. (2016). Geographic origin influences the phenolic composition and antioxidant potential of wild Crataegus monogyna from Spain. Pharm. Biol. 54(11): 2708-2713. doi:10.1080/13880209.2016.1179769.

Abu-Gharbieh, E., and Shehab, N.G. (2017). Therapeutic potentials of $\mathrm{Cra}-$ taegus azarolus var. eu-azarolus Maire leaves and its isolated compounds. BMC Complement. Altern. Med. 17(1): 218. doi:10.1186/ s12906-017-1729-9.

Agalou, A., Thrapsianiotis, M., Angelis, A., Papakyriakou, A., Skaltsounis, A.L., Aligiannis, N., and Beis, D. (2018). Identification of novel melanin synthesis inhibitors from Crataegus pycnoloba using an in vivo Zebrafish phenotypic assay. Front. Pharmacol. 9: 265. doi:10.3389/ fphar.2018.00265.

Akcan, T., Estévez, M., Rico, S., Ventanas, S., and Morcuende, D. (2017). Hawberry (Crataegus monogyna Jaqc.) extracts inhibit lipid oxidation and improve consumer liking of ready-to-eat (RTE) pork patties. J. Food Sci. Tech. Mys. 54(5): 1248-1255. doi:10.1007/s13197-0172578-8.

Aksoy-Sagirli, P., Yilmaz-Ozden, T., Ozsoy, N., Celik, B.O., Kultur, S., and Melikoglu, G. (2017). In vitro biological effects of Crataegus microphylla C. Koch. Indian J. Tradit. Know. 16(2): 189-196.

Al Humayed, S. (2017). Protective and therapeutic effects of Crataegus aronia in non-alcoholic fatty liver disease. Arch. Physiol. Biochem. 123(1): 23-30. doi:10.1080/13813455.2016.1205097.

Al Humayed, S., Eid, R.A., Shatoor, A.S., Haidara, M.A., Zaki, M.S.A., and Al-Ani, B. (2017). Differential therapeutic effects of Crataegus aronia and simvastatin on the hepatocyte ultrastructure in hepatic steatosis. Int. J. Morphol. 35(2): 578-583. doi:10.4067/S071795022017000200032.

Ali, M., Muhammad, S., Shah, M.R., Khan, A., Rashid, U., Farooq, U., Ullah, F., Sadiq, A., Ayaz, M., Ali, M., Ahmad, M., and Latif, A. (2017). Neurologically potent molecules from Crataegus oxyacantha; Isolation, anticholinesterase inhibition, and molecular docking. Front. Pharmacol. 8: 327. doi:10.3389/fphar.2017.00327.

Çalişkan, O. (2015). Chapter 55 - Mediterranean hawthorn fruit (Crataegus) species and potential usage. The Mediterranean Diet. An Evidence-Based Approach. In: Preedy, V.R., and Watson, R.R. (Ed.). Academic Press, London, pp. 621-628.

Alirezalu, A., Salehi, P., Ahmadi, N., Sonboli, A., Aceto, S., Maleki, H.H., and Ayyari, M. (2018). Flavonoids profile and antioxidant activity in flowers and leaves of hawthorn species (Crataegus spp.) from different regions of Iran. Int. J. Food Prop. 21(1): 452-470. doi:10.1080/1094 2912.2018.1446146

Alp, H., Soner, B.C., Baysal, T., and Sahin, A.S. (2015). Protective effects of hawthorn (Crataegus oxyacantha) extract against digoxin-induced arrhythmias in rats. Anatolian J. Cardiol. 15(12): 970-975. doi:10.5152/akd.2014.5869.

Aral, S., and Bese, A.V. (2016). Convective drying of hawthorn fruit (Crataegus spp.): Effect of experimental parameters on drying kinetics, color, shrinkage, and rehydration capacity. Food Chem. 210: 577-584. doi:10.1016/j.foodchem.2016.04.128.

Arslan, R., Bektas, N., Bor, Z., and Sener, E. (2015). Evaluation of the antithrombotic effects of Crataegus monogyna and Crataegus davisii in the carrageenan-induced tail thrombosis model. Pharm. Biol. 53(2): 275-279. doi:10.3109/13880209.2014.914957.

Šavikin, K.P., Krstić-Milošević, D.B., Menković, N.R., Beara, I.N., Mrkonjić, Z.O., and Pljevljakušić, D.S. (2017). Crataegus orientalis leaves and berries: Phenolic profiles, antioxidant and anti-inflammatory activity. Nat. Prod. Commun. 12(2): 159-162.

Bae, Y., and Kim, Y.K. (2017). Evaluation of biological activity on hawthorn tree (Crataegus pinnatifida) extracts. J. Korean Wood Sci. Technol. 45(3): 317-326.

Bekbolatova, E., Kukula-Koch, W., Baj, T., Stasiak, N., Ibadullayeva, G., 
Koch, W., Glowniak, K., Tulemissov, S., Sakipova, Z., and Boylan, F. (2018). Phenolic composition and antioxidant potential of different organs of Kazakh Crataegus almaatensis Pojark: A comparison with the European Crataegus oxyacantha L. flowers. Open Chem. 16(1) 415-426. doi:10.1515/chem-2018-0048.

Belkhir, M., Dhaouadi, K., Rosa, A., Atzeri, A., Nieddu, M., Tuberoso, C.I.G., Rescigno, A., Amri, M., and Fattouch, S. (2016). Protective effects of azarole polyphenolic extracts against oxidative damage using in vitro biomolecular and cellular models. Ind. Crops Prod. 86: 239-250. doi:10.1016/j.indcrop.2016.04.003.

Belz, G.G., and Loew, D. (2003). Dose-response related efficacy in orthostatic hypotension of a fixed combination of D-camphor and an extract from fresh Crataegus berries and the contribution of the single components. Phytomedicine 10: 61-67. doi:10.1078/1433-187X-00303.

Benabderrahmane, W., Lores, M., Lamas, J.P., and Benayache, S. (2018). Matrix solid-phase dispersion as a tool for phytochemical and bioactivities characterisation: Crataegus oxyacantha L. A case study. Nat. Prod. Res. 32(10): 1220-1223. doi:10.1080/14786419.2017.1326040.

Bisignano, C., Furneri, P.M., and Mandalari, G. (2016). In vitro efficacy of Crataegus oxycantha L. (hawthorn) and its major components against ATCC and clinical strains of Ureaplasma urealyticum. Adv. Microbiol. 6(12): 909-916. doi:10.4236/aim.2016.612085.

Bjorklund, G., Dadar, M., Martins, N., Chirumbolo, S., Goh, B.H., Smetanina, K., and Lysiuk, R. (2018). Brief challenges on medicinal plants: An eye-opening look at ageing-related disorders. Basic Clin. Pharmacol. Toxicol. 122(6): 539-558. doi:10.1111/bcpt.12972.

Bura, F.T., Firuzja, R.A., and Nemati, F. (2016). Cytotoxic effect of the flower and leaf bud extract of Crataegus Microphylla $\mathrm{C}$. Koch on hela cell line. IIOAB J. 7: 214-218.

Cakir, S., Orallar, H., Cetinkaya, A., Kayacan, Y., Onal, A.C., Yildirim, A., Beyazcicek, E., Benek, S., Ozkan, M., Ince, O.B., and Okur, N. (2016). Ameliorating effect of hawthorn (Crataegus oxyacantha) and physical exercise on acute penicillin induced seizures in gerbils. Afr. J. Tradit. Complement. Altern. Med., Nigeria 13(2): 223-228. doi:10.4314/ ajtcam.v13i2.26.

Cervantes-Paz, B., Ornelas-Paz, J.D., Gardea-Béjar, A.A., Yahia, E.M., RiosVelasco, C., Zamudio-Flores, P.B., Ruiz-Cruz, S., and Ibarra-Junquera, V. (2018). Phenolic compounds of hawthorn (Crataegus spp.): Their biological activity associated to the protection of human health. Rev. Fitotec. Mex. 41(3): 339-349.

Chaabani, G., Tabart, J., Kevers, C., Dommes, J., Khan, M.I., Zaoui, S., Chebchoub, L., Lachaal, M., and Karray-Bouraoui, N. (2015). Effects of 2,4-dichlorophenoxyacetic acid combined to 6-Benzylaminopurine on callus induction, total phenolic and ascorbic acid production, and antioxidant activities in leaf tissue cultures of Crataegus azarolus L. var. aronia. Acta Physiol. Plant. 37(2): 16. doi:10.1007/s11738-0141769-4.

Chang, W.T., Dao, J., and Shao, Z.H. (2005). Hawthorn: Potential roles in cardiovascular disease. Am. J. Chin. Med. 33(1): 1-10. doi:10.1142/ S0192415X05002606.

Chen, L.L., Zhang, B., Shan, S.Q., and Zhao, X. (2016). Neuroprotective effects of vitexin against isoflurane-induced neurotoxicity by targeting the TRPV1 and NR2B signaling pathways. Mol. Med. Rep. 14(6): 5607-5613. doi:10.3892/mmr.2016.5948

Chen, Z.Y., Peng, C., Jiao, R., Wong, Y.M., Yang, N., and Huang, Y. (2009). Anti-hypertensive nutraceuticals and functional foods. J. Agric. Food Chem. 57(11): 4485-4499. doi:10.1021/jf900803r.

Chen, S.Y., Teng, R.H., Wang, M.L., Chen, P.L., Lin, M.C., Shen, C.H., Chao, C.N., Chiang, M.K., Fang, C.Y., and Chang, D.C. (2017). Rhodiolae Kirliowii Radix et Rhizoma and Crataegus pinnatifida Fructus extracts effectively inhibit BK virus and JC virus infection of host cells. Evid. Based Complement. Alternat. Med. 2017: 5620867.

Cheng, Q., Zhang, X.F., Wang, O., Liu, J., Cai, S.B., Wang, R.J., Zhou, F., and Ji, B.P. (2015). Anti-diabetic effects of the ethanol extract of a functional formula diet in mice fed with a fructose/fat-rich combination diet. J. Sci. Food Agric. 95(2): 401-408. doi:10.1002/jsfa.6737.

Cui, K., Zhang, S.B., Jiang, X., and Xie, W.D. (2016). Novel synergic antidiabetic effects of Astragalus polysaccharides combined with Crataegus flavonoids via improvement of islet function and liver metabolism. Mol. Med. Rep. 13(6): 4737-4744. doi:10.3892/mmr.2016.5140.

Dahmer, S., and Scott, E. (2010). Health effects of hawthorn. Am. Fam.
Physician. 81(4): 465-468.

Dallak, M. (2018). Crataegus aronia enhances sperm parameters and preserves testicular architecture in both control and non-alcoholic fatty liver disease-induced rats. Pharm. Biol. 56(1): 535-547. doi:10.1080 /13880209.2018.1523934

Dennehy, C. (2001). Botanicals in cardiovascular health. Clin. Obstet. Gynecol. 44(4): 814-823. doi:10.1097/00003081-200112000-00019.

De Quadros, A.P.O., Mazzeo, D.E.C., Marin-Morales, M.A., Perazzo, F.F. Rosa, P.C.P., and Maistro, E.L. (2017). Fruit extract of the medicinal plant Crataegus oxyacantha exerts genotoxic and mutagenic effects in cultured cells. J. Toxicol. Environ. Health A. 80(3): 161-170. doi:10 $.1080 / 15287394.2016 .1272517$.

Dong, Y., Liao, J.Q., Yao, K.W., Jiang, W.R., and Wang, J. (2017). Application of traditional Chinese Medicine in treatment of atrial fibrillation. Evid. Based Complement. Alternat. Med. 2017: 1381732.

Dong, P.Z., Pan, L.L., Zhang, X.T., Zhang, W.W., Wang, X., Jiang, M.X., Chen, Y.L., Duan, Y.J., Wu, H.H., Xu, Y.T., Zhang, P., and Zhu, Y. (2017). Hawthorn (Crataegus pinnatifida Bunge) leave flavonoids attenuate atherosclerosis development in apoE knock-out mice. J. Ethnopharmacol. 198: 479-488. doi:10.1016/j.jep.2017.01.040.

Dou, D.Q., Leng, P.S., Li, Y.H., Zeng, Y., and Sun, Y.X. (2015). Comparative study of antioxidant compounds and antiradical properties of the fruit extracts from three varieties of Crataegus pinnatifida. J. Food Sci. Technol. 52(1): 430-436. doi:10.1007/s13197-013-0954-6.

Ebrahimzadeh, M.A., Khalili, M., Jafari, N., Zareh, G., Farzin, D., and Amin G. (2018). Antihypoxic activities of Crataegus pentaegyn and Crataegus microphylla fruits-an in vivo assay. Braz. J. Pharm. Sci. 54(2):

Edwards, J.E., Paula, P.N., Brown, N., Talent, N., Dickinson, T.A., and García-Mateos and Shipley, P.R. (2012). A review of the chemistry of the genus Crataegus. Phytochem. 79: 5-26. doi:10.1016/j.phytochem.2012.04.006

Elaine, W., Wang, Y.P., Ken, C., Wai, L.H., Man, K.C., Man, L.K., Chung, L.P., Choly, Y., and San, L.C.B. (2018). An in vitro and in vivo study of a 4-herb formula on the management of diet-induced metabolic syndrome. Phytomedicine 42: 112-125. doi:10.1016/j.phymed.2018.03.028.

Ercisli, S., Yanar, M., Sengul, M., Yildiz, H., Topdas, E.F., Taskin, T., Zengin, Y., and Yilmaz, K.U. (2015). Physico-chemical and biological activity of hawthorn (Crataegus spp. L.) fruits in Turkey. Acta Sci. Pol. Hortorum Cultus 14(1): 83-93.

Fei, C.H., Dai, H., Wu, X.Y., Li, L., Lu, T.L., Li, W.D., Cai, B.C., Yin, W., and Yin, F.Z. (2018). Quality evaluation of raw and processed Crataegi Fructus by color measurement and fingerprint analysis. J. Sep. Sci. 41(2): 582-589. doi:10.1002/jssc.201700575.

Fong, H., and Bauman, J. (2002). Alternative medicines for cardiovascular diseases: Hawthorn. J. Cardiovasc. Nurs. 16: 1-8.

Fu, T., Wang, L., Jin, X.N., Sui, H.J., Liu, Z., and Jin, Y. (2016). Hyperoside induces both autophagy and apoptosis in non-small cell lung cancer cells in vitro. Acta Pharmacol. Sin. 37(4): 505-518. doi:10.1038/ aps.2015.148

Fuchs, S., Bischoff, I., Willer, E.A., Bräutigam, J., Bubik, M.F., Erdelmeier, C.A.J., Koch, E., Faleschini, M.T., De Mieri, M., Bauhart, M., Zahler, S., Hensel, A., Hamburger, M., Potterat, O., and Fürst, R. (2017). The dual edema-preventing molecular mechanism of the Crataegus extract WS 1442 can be assigned to distinct phytochemical fractions. Planta Med. 83(8): 701-709.

Ganie, S.A., Dar, T.A., Zargar, S., Bhat, A.H., Dar, K.B., Masood, A., and Zargar, M.A. (2016). Crataegus songarica methanolic extract accelerates enzymatic status in kidney and heart tissue damage in albino rats and its in vitro cytotoxic activity. Pharm. Biol. 54(7): 1246-1254. doi:10.3 109/13880209.2015.1066398.

Gao, P.Y., Li, L.Z., Liu, K.C., Sun, C., Sun, X., Wu, Y.N., and Song, S.J. (2017) Natural terpenoid glycosides with in vitro/vivo antithrombotic profiles from the leaves of Crataegus pinnatifida. RSC Adv. 7(76): 4846648474. doi:10.1039/C7RA10768D.

González-Jiménez, F.E., Salazar-Montoya, J.A., Calva-Calva, G., and RamosRamírez, E.G. (2018). Phytochemical characterization, in vitro antioxidant activity, and quantitative analysis by micellar electrokinetic chromatography of hawthorn (Crataegus pubescens) fruit. J. Food Qual. 2018: 2154893.

Granato, D., Shahidi, F., Wrolstad, R., Kilmartin, P., Melton, L.D., Hidalgo, F.J., Miyashita, K., van Camp, J., Alasalvar, C., Ismail, A.B., Elmore, S. 
Birch, G.G., Charalampopoulos, D., Astley, S.B., Pegg, R., Zhou, P., and Finglas, P. (2018). Antioxidant activity, total phenolics and flavonoids contents: Should we ban in vitro screening methods? Food Chem 264: 471-475. doi:10.1016/j.foodchem.2018.04.012.

Guo, R., Lin, B., Shang, X.Y., Zhou, L., Yao, G.D., Huang, X.X., and Song, S.J. (2018). Phenylpropanoids from the fruit of Crataegus pinnatifida exhibit cytotoxicity on hepatic carcinoma cells through apoptosis induction. Fitoterapia 127: 301-307. doi:10.1016/j.fitote.2018.03.003.

Halver, J., Garcia, C.C., Willems, E., and Schade, D. (2015). Crataegus ssp promotes late-stage cardiac differentiation and regeneration. Planta Med. 81(16): 1509-1509. Meeting Abstract: PW-61.

Han, F., Guo, Y.P., Gu, H.Y., Li, F.L., Hu, B.Z., and Yang, L. (2016a). Application of alkyl polyglycoside surfactant in ultrasonic-assisted extraction followed by macroporous resin enrichment for the separation of vitexin-2"-O-rhamnoside and vitexin from Crataegus pinnatifida leaves. J. Chromatogr. B 1012: 69-78.

Han, X., Li, W.F., Huang, D., and Yang, X.B. (2016b). Polyphenols from hawthorn peels and fleshes differently mitigate dyslipidemia, inflammation and oxidative stress in association with modulation of liver injury in high fructose diet-fed mice. Chem. Biol. Interact. 257: 132-140. doi:10.1016/j.cbi.2016.08.002.

Hatipoglu, M., Saglam, M., Koseoglu, S., Koksal, E., Keles, A., and Esen, H.H. (2015). The effectiveness of Crataegus orientalis M Bieber. (Hawthorn) extract administration in preventing alveolar bone loss in rats with experimental periodontitis. PLoS ONE 10(6): e0128134. doi:10.1371/journal.pone.0128134.

Haydari, M.R., Panjeshahin, M.R., Mashghoolozekr, E., and Nekooeian, A.A. (2017). Antihypertensive effects of hydroalcoholic extract of Crataegus Azarolus subspecies Aronia fruit in rats with renovascular hypertension: An experimental mechanistic study. Iran. J. Med. Sci. 42(3): 266-274.

He, M., Min, J.W., Kong, W.L., He, X.H., Li, J.X., and Peng, B.W. (2016). A review on the pharmacological effects of vitexin and isovitexin. Fitoterapia 115: 74-85. doi:10.1016/j.fitote.2016.09.011.

Hellenbrand, N., Sendker, J., Lechtenberg, M., Petereit, F., and Hensel, A. (2015). Isolation and quantification of oligomeric and polymeric procyanidins in leaves and flowers of hawthorn (Crataegus spp.). Fitoterapia. 104: 14-22. doi:10.1016/j.fitote.2015.04.010.

Holubarsch, C.J.F., Colucci, W.S., and Eha, J. (2018). Benefit-risk assessment of Crataegus extract WS 1442: An evidence-based review. Am. J. Cardiovasc. Drugs 18(1): 25-36. doi:10.1007/s40256-017-0249-9.

Houston, M.C. (2005). Nutraceuticals, vitamins, antioxidants, and minerals in the prevention and treatment of hypertension. Prog. Cardiovasc. Dis. 47(6): 396-449. doi:10.1016/j.pcad.2005.01.004.

Hu, M., Li, F.M., and Wang, W.D. (2018). Vitexin protects dopaminergic neurons in MPTP-induced Parkinson's disease through PI3K/Akt signaling pathway. Drug Des. Dev. Ther. 12: 565-573. doi:10.2147/DDDT. S156920.

Huang, X.X., Bai, M., Zhou, L., Lou, L.L., Liu, Q.B., Zhang, Y., Li, L.Z., and Song, S.J. (2015a). Food byproducts as a new and cheap source of bioactive compounds: Lignans with antioxidant and anti-inflammatory properties from Crataegus pinnatifida seeds. J. Agric. Food Chem. 63(32): 7252-7260. doi:10.1021/acs.jafc.5b02835.

Huang, X.X., Liu, Q.B., Zhou, L., Liu, S., Cheng, Z.Y., Sun, Q., Li, L.Z., and Song, S.J. (2015b). The antioxidant and tyrosinase-inhibiting activities of 8-0-4' neolignans from Crataegus pinnatifida Seeds. Rec. Nat. Prod. 9(3): 305-311.

Huang, X.X., Ren, Q., Song, X.Y., Zhou, L., Yao, G.D., Wang, X.B., and Song, S.J. (2018a). Seven new sesquineolignans isolated from the seeds of hawthorn and their neuroprotective activities. Fitoterapia 125: 6-12. doi:10.1016/j.fitote.2017.12.010.

Huang, X.X., Xu, Y., Bai, M., Zhou, L., Song, S.J., and Wang, X.B. (2018b). Lignans from the seeds of Chinese hawthorn (Crataegus pinnatifida var. major NEBr.) against $\beta$-amyloid aggregation. Nat. Prod. Res. 32(14): 1706-1713. doi:10.1080/14786419.2017.1399378.

Hwang, E., Park, S.Y., Yin, C.S., Kim, H.T., Kim, Y.M., and Yi, T.H. (2017). Antiaging effects of the mixture of Panax ginseng and Crataegus pinnatifida in human dermal fibroblasts and healthy human skin. J. Ginseng Res. 41(1): 69-77. doi:10.1016/j.jgr.2016.01.001.

Jalaly, L., Sharifi, G., Faramarzi, M., Nematollahi, A., Rafieian-Kopaei, M., Amiri, M., and Moattar, F. (2015). Comparison of the effects of Cra- taegus oxyacantha extract, aerobic exercise and their combination on the serum levels of ICAM-1 and E-Selectin in patients with stable angina pectoris. Daru J. Pharm. Sci. 23: 54. doi:10.1186/s40199-0150137-2.

Jin, X.N., Yan, E.Z., Wang, H.M., Sui, H.J., Liu, Z., Gao, W., and Jin, Y. (2016). Hyperoside exerts anti-inflammatory and antiarthritic effects in LPSstimulated human fibroblast-like synoviocytes in vitro and in mice with collagen-induced arthritis. Acta Pharmacol. Sin. 37(5): 674-686. doi:10.1038/aps.2016.7.

Jung, D., and Shim, J. (2017). Crataegus pinnatifida extract increases lifespan of Drosophila melanogaster. Mol. Biol. Cell 28: Meeting Abstract: P3476.

Jurikova, T., Sochor, J., Rop, O., Mlcek, J., Balla, S., Szekeres, L., Adam, V., and Kizek, R. (2012). Polyphenolic profile and biological activity of Chinese hawthorn (Crataegus pinnatifida BUNGE) fruits. Molecules 17: 14490-14509. doi:10.3390/molecules171214490.

Kalantari, H., Hemmati, A.A., Goudarzi, M., Forouzandeh, H., Kalantar, M., Aghel, N., Aslani, M.K., and Ehsan, T.S. (2016). Healing Effect of Hawthorn (Crataegus pontica C. Koch) Leaf Extract in Dermal Toxicity Induced by T-2 Toxin in Rabbit. Jundishapur J. Nat. Pharm. Prod. 11(3).

Kallassy, H., Fayyad-Kazan, M., Makki, R., El-Makhour, Y., Hamade, E., Rammal, H., Leger, D.Y., Sol, V., Fayyad-Kazan, H., Liagre, B., and Badran, B. (2017). Chemical composition, anti-oxidant, anti-inflammatory, and antiproliferative activities of the plant Lebanese Crataegus azarolus L. Med. Sci. Monit. Basic Res. 23: 270-284. doi:10.12659/ MSMBR.905066.

Kang, I. (2015). Anti-diabetic and anti-oxidative activities of extracts from Crataegus pinnatifida. J. East Asian Soc. Diet. Life 25(2): 270-277. doi:10.17495/easdl.2015.4.25.2.270.

Kanmanthareddy, A., Reddy, M., Ponnaganti, G., Sanjani, H.P., Koripalli, S., Adabala, N., Buddam, A., Janga, P., Lakkireddy, T., Bommana, S., Vallakati, A., Atkins, D., and Lakkireddy, D. (2015). Alternative medicine in atrial fibrillation treatment-Yoga, acupuncture, biofeedback and more. J. Thorac. Dis. 7(2): 185-192.

Kazuma, K., Isobe, Y., Asahina, H., Nehira, T., Satake, M., and Konno, K. (2016). Crataegusins A and B, new flavanocoumarins from the dried fruits of Crataegus pinnatifida var. major (Rosaceae). Nat. Prod. Commun. 11(7): 965-969.

Koch, E., and Malek, F.A. (2011). Standardized extracts from hawthorn leaves and flowers in the treatment of cardiovascular disorders - Preclinical and clinical studies. Planta Med. 77(11): 1123-1128. doi:10. 1055/s-0030-1270849.

Kowalski, R., Kowalska, G., Kałwa, K., and Sujka, M. (2018). Essential oil composition of hawthorn Crataegus monogyna inflorescence. Chem. Nat. Comp. 54(5): 995-997. doi:10.1007/s10600-018-2533-6.

Kumar, D., Arya, V., Bhat, Z.A., Khan, N.A., and Prasad, D.N. (2012). The genus Crataegus: Chemical and pharmacological perspectives. Rev. Bras. Farmacogn. 22(5): 1187-1200. doi:10.1590/S0102 $695 \times 2012005000094$.

Kwon, Y.R. (2016). Antioxidant abilities and physiological properties of dried Haw extracts prepared using different drying methods. Korean J. Food Preserv. 23(2): 246-251. doi:10.11002/kjfp.2016.23.2.246.

Lakache, Z., Tigrine-Kordjani, N., Tigrine, C., Aliboudhar, H., and Kameli, A. (2016). Phytochemical screening and antioxidant properties of methanolic extract and different fractions of Crataegus azarolus leaves and flowers from Algeria. Intern. Food Res. J. 23(4): 1576-1583.

Lee, Y.H., Kim, Y.S., Song, M., Lee, M., Park, J., and Kim, H. (2015). A herbal formula HTO48, Citrus unshiu and Crataegus pinnatifida, prevents obesity by inhibiting adipogenesis and lipogenesis in 3T3-L1 preadipocytes and HFD-induced obese rats. Molecules 20(6): 9656-9670. doi:10.3390/molecules20069656.

Lee, Y.H., Jin, B., Lee, S.H., Song, M., Bae, H., Min, B.J., Park, J., Lee, D., and Kim, H. (2016). Herbal formula HTO48 attenuates diet-induced obesity by improving hepatic lipid metabolism and insulin resistance in obese rats. Molecules. 21(11): 1424. doi:10.3390/molecules 21111424.

Li, W.Q., Hu, Q.P., and Xu, J.G. (2015). Changes in physicochemical characteristics and free amino acids of hawthorn (Crataegus pinnatifida) fruits during maturation. Food Chem. 175: 50-56. doi:10.1016/j. foodchem.2014.11.125.

Li, L.Z., Gao, P.Y., Song, S.J., Yuan, Y.Q., Liu, C.T., Huang, X.X., and Liu, Q.B. 
(2015). Monoterpenes and flavones from the leaves of Crataegus pinnatifida with anticoagulant activities. J. Funct. Foods. 12: 237245. doi:10.1016/j.jff.2014.11.012.

Li, Z.P., Xu, J.Y., Zheng, P.Y., Xing, L.J., Shen, H.Y., Yang, L.L., Zhang, L., and Ji, G. (2015). Hawthorn leaf flavonoids alleviate nonalcoholic fatty liver disease by enhancing the adiponectin/AMPK pathway. Int. J. Clin. Exp. Med. 8(10): 17295-17307.

Li, W.H., and Yang, N. (2016). Green and facile synthesis of $\mathrm{Ag}-\mathrm{Fe}_{3} \mathrm{O}_{4}$ nanocomposites using the aqueous extract of Crataegus pinnatifida leaves and their antibacterial performance. Mater. Lett. 162: 157160. doi:10.1016/j.matlet.2015.09.064.

Lim, D.W., Han, T., Jung, J., Song, Y., Um, M.Y., Yoon, M., Kim, Y.T., Cho, S. Kim, I.H., Han, D., Lee, C., and Lee, J. (2018). Chlorogenic acid from hawthorn berry (Crataegus pinnatifida Fruit) prevents stress hormone-induced depressive behavior, through monoamine oxidase Breactive oxygen species signaling in hippocampal astrocytes of mice. Mol. Nutr. Food Res. 62(15): 1800029. doi:10.1002/mnfr.201800029.

Linares-Garcia, J.A., Ramos-Ramirez, E.G., and Salazar-Montoya, J.A. (2015). Viscoelastic properties and textural characterisation of high methoxyl pectin of hawthorn (Crataegus pubescens) in a gelling system. Int. J. Food Sci. Technol. 50(6): 1484-1493. doi:10.1111/ ijfs.12792.

Liu, S.W., Chang, X.D., Liu, X.F., and Shen, Z.W. (2016). Effects of pretreatments on anthocyanin composition, phenolics contents and antioxidant capacities during fermentation of hawthorn (Crataegus pinnatifida) drink. Food Chem. 212: 87-95. doi:10.1016/j.foodchem.2016.05.146.

Liu, C.Q., and Huang, Y. (2016). Chinese herbal medicine on cardiovascular diseases and the mechanisms of action. Front. Pharmacol. 7: 469.

Liu, S.W., You, L., Zhao, Y.X., and Chang, X.D. (2018). Hawthorn polyphenol extract inhibits UVB-induced skin photoaging by regulating MMP expression and Type I procollagen production in mice. J. Agric. Food Chem. 66(32): 8537-8546. doi:10.1021/acs.jafc.8b02785.

Liu, S.W., Zhang, X., You, L., Guo, Z.Y., and Chang, X.D. (2018). Changes in anthocyanin profile, color, and antioxidant capacity of hawthorn wine (Crataegus pinnatifida) during storage by pretreatments. LWT Food Sci. Technol. 95: 179-186. doi:10.1016/j.Iwt.2018.04.093.

Loew, D. (1997). Phytotherapy in heart failure. Phytomedicine 4(3): 267271. doi:10.1016/S0944-7113(97)80080-3.

Lozano-Grande, M.A., Valle-Guadarrama, S., Aguirre-Mandujano, E., Lobato-Calleros, C.S.O., and Huelitl-Palacios, F. (2016). Films based on hawthorn (Crataegus spp.) fruit pectin and candelilla wax emulsions: Characterization and application on Pleurotus ostreatus. Agrociencia-Mexico. 50(7): 849-866.

Luo, M., Hu, J.Y., Song, Z.Y., Jiao, J., Mu, F.S., Ruan, X., Gai, Q.Y., Qiao, Q., Zu, Y.G., and Fu, Y.J. (2015). Optimization of ultrasound-assisted extraction (UAE) of phenolic compounds from Crataegus pinnatifida leaves and evaluation of antioxidant activities of extracts. RSC Adv. 5(83): 67532-67540. doi:10.1039/C5RA07445B.

Luo, C., Ke, Y.T., Yuan, Y.Y., Zhao, M., Wang, F.Y., Zhang, Y.S., and Bu, S.Z. (2016). A novel herbal treatment reduces depressive-like behaviors and increases brain-derived neurotrophic factor levels in the brain of type 2 diabetic rats. Neuropsychiatr. Dis. Treat. 12: 3051-3059. doi:10.2147/NDT.S117337.

Luo, L., Zhen, L.F., Xu, Y.T., Yang, Y.X., Feng, S.X., Wang, S.M., and Liang, S.W. (2016). H-1 NMR-based metabonomics revealed protective effect of Naodesheng bioactive extract on ischemic stroke rats. J. Ethnopharmacol. 186: 257-269. doi:10.1016/j.jep.2016.03.059.

Luo, M., Yang, X., Hu, J.Y., Jiao, J., Mu, F.S., Song, Z.Y., Gai, Q.Y., Qiao, Q., Ruan, X., and Fu, Y.J. (2016). Antioxidant properties of phenolic compounds in renewable parts of Crataegus pinnatifida inferred from seasonal variations. J. Food Sci. 81(5): C1102-C1109. doi:10.1111/1750-3841.13291.

Mahmud, S.A., Al-Habib, O.A.M., Bugoni, S., Clericuzio, M., and Vidari, G. (2016). A new ursane-type triterpenoid and other constituents from the leaves of Crataegus azarolus var. aronia. Nat. Prod. Commun. 11(11): 1637-1639.

Miao, J., Li, X., Fan, Y.Y., Zhao, C.C., Mao, X.H., Chen, X.T., Huang, H.H., and Gao, W.Y. (2016). Effect of different solvents on the chemical composition, antioxidant activity and $\alpha$-glucosidase inhibitory activity of hawthorn extracts. Int. J. Food Sci. Technol. 51(5): 1244-1251. doi:10.1111/ijfs.13076

Min, Q., Bai, Y.T., Zhang, Y.C., Yu, W., Zhang, M.L., Liu, D.Y., Diao, T.T., and Lv, W. (2017). Hawthorn leaf flavonoids protect against diabetesinduced cardiomyopathy in rats via PKC- $\alpha$ signaling pathway. Evid. Based Complement. Alternat. Med. 2017: 2071952.

Moradi, M.T., Karimi, A., Alidadi, S., and Hashemi, L. (2018). In vitro antiherpes simplex virus activity, antioxidant potential and total phenolic compounds of selected Iranian medicinal plant extracts. Indian J. Tradit. Know. 17(2): 255-262.

Mostafa, D.G., Khaleel, E.E., and Abdel-Aleem, G.A. (2018). Inhibition of the hepatic glucose output is responsible for the hypoglycemic effect of Crataegus aronia against type 2 diabetes mellitus in rats. Arch. Biol. Sci. 70(2): 277-287. doi:10.2298/ABS170510044M.

Mraihi, F., Hidalgo, M., de Pascual-Teresa, S., Trabelsi-Ayadi, M., and Cherif, J.K. (2015). Wild grown red and yellow hawthorn fruits from Tunisia as source of antioxidants. Arab. J. Chem. 8(4): 570-578. doi:10.1016/j.arabjc.2014.11.045.

Muresan, A.E., Muste, S., Petrut, G., Vlaic, R.A., Man, S.M., and Muresan, V. (2016). New uses of hawthorn fruits in tonic wines technology. Bull. Univ. Agric. Sci. Vet. Med. Cluj Napoca 73(2) 117-122: 12327

Mustapha, N., Bzeouich, I.M., Ghedira, K., Hennebelle, T., and ChekirGhedira, L. (2015). Compounds isolated from the aerial part of Crataegus azarolusinhibit growth of B16F10 melanoma cells and exert a potent inhibition of the melanin synthesis. Biomed. Pharmacother. 69: 139-144. doi:10.1016/j.biopha.2014.11.010.

Mustapha, N., Mokdad-Bzeouich, I., Sassi, A., Abed, B., Ghedira, K., Hennebelle, T., and Chekir-Ghedira, L. (2016a). Immunomodulatory potencies of isolated compounds from Crataegus azarolus through their antioxidant activities. Tumor Biol. 37(6): 7967-7980. doi:10.1007/ s13277-015-4517-5.

Mustapha, N., Mokdad-Bzeouich, I., Maatouk, M., Ghedira, K., Hennebelle, T., and and Chekir-Ghedira, L. (2016b). Antitumoral, antioxidant, and antimelanogenesis potencies of hawthorn, a potential natural agent in the treatment of melanoma. Melanoma Res. 26(3): 211-222. doi:10.1097/CMR.0000000000000240.

Mustapha, N., Pinon, A., Limami, Y., Simon, A., Ghedira, K., Hennebelle, T., and Chekir-Ghedira, L. (2016c). Crataegus azarolus leaves induce antiproliferative activity, cell cycle arrest, and apoptosis in human HT-29 and HCT-116 colorectal cancer cells. J. Cell. Biochem. 117(5): 1262-1272. doi:10.1002/jcb.25416.

Nabavi, S.F., Habtemariam, S., Ahmed, T., Sureda, A., Daglia, M., SobarzoSanchez, E., and Nabavi, S.M. (2015). Polyphenolic composition of Crataegus monogyna Jacq.: From chemistry to medical applications. Nutrients 7(9): 7708-7728. doi:10.3390/nu7095361.

Nunes, M.A., Rodrigues, F., Alves, R.C., and Oliveira, M.B.P.P. (2017) Herbal products containing Hibiscus sabdariffa L., Crataegus spp. and Panax spp.: Labeling and safety concerns. Food Res. Int. 100 529-540. doi:10.1016/j.foodres.2017.07.031.

Čopra-Janićijević, A., Čulum, D., Vidic, D., Tahirović, A., Klepo, L., and Bašić, N. (2018). Chemical composition and antioxidant activity of the endemic Crataegus microphylla Koch subsp malyana K. I. Chr. \& Janjić from Bosnia. Ind. Crops Prod. 113: 75-79. doi:10.1016/j.indcrop.2018.01.016.

Ozay, C., Mammadov, R., Tasdelen, G., Karagur, E.R., and Akca, H. (2015). Potential antioxidant, antiproliferative and hepatoprotective effects of Crataegus Meyeri. J. Food Biochem. 39(5): 548-553. doi:10.1111/ jfbc. 12161.

Ozderin, S., Fakir, H., and Donmez, I.E. (2016). Chemical properties of hawthorn (Crataegus L. spp.) taxa naturally distributed in Western Anatolia part of turkey. Sumarski List. 140(7-8): 369-376. doi:10.31298/ sl.140.7-8.5.

Pahlavan, S., Tousi, M.S., Ayyari, M., Alirezalu, A., Ansari, H., Saric, T., and Baharvand, H. (2018). Effects of hawthorn (Crataegus pentagyna) leaf extract on electrophysiologic properties of cardiomyocytes derived from human cardiac arrhythmia-specific induced pluripotent stem cells. FASEB J. 32(3): 1440-1451. doi:10.1096/fj.201700494RR.

Pang, X.C., Kang, D., Fang, J.S., Zhao, Y., Xu, L.J., Lian, W.W., Liu, A.L., and Du, G.H. (2018). Network pharmacology-based analysis of Chinese herbal Naodesheng formula for application to Alzheimer's disease. CJNM. 16(1): 53-62.

Papuc, C., Predescu, C.N., Tudoreanu, L., Nicorescu, V., and Gâjâilă, I. 
(2018). Comparative study of the influence of hawthorn (Crataegus monogyna) berry ethanolic extract and butylated hydroxylanisole (BHA) on lipid peroxidation, myoglobin oxidation, consistency and firmness of minced pork during refrigeration. J. Sci. Food Agric. 98(4): 1346-1361. doi:10.1002/jsfa.8599.

Park, S.-J., Kwon, S.-P., and Rha, Y.-A. (2017a). Antioxidative activities and whitening effects of ethanol extract from Crataegus pinnatifida Bunge Fruit. J. Korean Soc. Food Sci. Nutr. 46(10): 1158-1163.

Park, S.-J., Kwon, S.-P., and Rha, Y.-A. (2017b). Enhancement of antioxidant activities of Crataegus pinnatifida Bunge fruit by ultrasonification extraction processes. J. Korean Soc. Food Sci. Nutr. 46(7): 891-895.

Pawlaczyk-Graja, I. (2018). Polyphenolic-polysaccharide conjugates from flowers and fruits of single-seeded hawthorn (Crataegus monogyna Jacq.): Chemical profiles and mechanisms of anticoagulant activity. Int. J. Biol. Macromol. 116: 869-879. doi:10.1016/j.ijbiomac.2018.05.101.

Peng, Y., Lou, L.L., Liu, S.F., Zhou, L., Huang, X.X., and Song, S.J. (2016). Antioxidant and anti-inflammatory neolignans from the seeds of hawthorn. Bioorg. Med. Chem. Lett. 26(22): 5501-5506. doi:10.1016/j. bmcl.2016.10.012.

Phipps, J.B., O'Kennon, R.J., and Lance, R.W. (2003). Hawthorns and Medlars. Royal Horticultural Society, Cambridge U.K.

Pittler, M.H., Schmidt, K., and Ernst, E. (2003). Hawthorn extract for treating chronic heart failure: Meta-analysis of randomized trials. Am. J. Med. 114(8): 665-674.(03)00131-1. doi:10.1016/S00029343(03)00131-1.

Pliszka, B., Huszcza-Ciolkowska, G., and Wierzbicka, E. (2016). Effects of solvents and extraction methods on the content and antiradical activity of polyphenols from fruits Actinidia arguta, Crataegus monogyna, Gaultheria procumbens and Schisandra chinensis. Acta Sci. Pol. Technol. Aliment. 15(1): 57-63. doi:10.17306/J.AFS.2016.1.6.

Qiao, A.M., Wang, Y.H., Xiang, L.M., Zhang, Z.X., and He, X.J. (2015). Novel triterpenoids isolated from hawthorn berries functioned as antioxidant and antiproliferative activities. J. Funct. Foods 13: 308-313. doi:10.1016/j.jff.2014.12.047.

Rababa'h, A.M., Altarabsheh, S.E., Haddad, O., Deo, S.V., Obeidat, Y., and Al-Azzam, S. (2016). Hawthorn herb increases the risk of bleeding after cardiac surgery: An evidence-based approach. Heart Surg. Forum 19(4): E175-E179. doi:10.1532/hsf.1570.

Ranjbar, K., Zarrinkalam, E., Salehi, I., Komaki, A., and Fayazi, B. (2018). Cardioprotective effect of resistance training and Crataegus oxyacantha extract on ischemia reperfusion-induced oxidative stress in diabetic rats. Biomed. Pharmacother. 100: 455-460. doi:10.1016/j. biopha.2018.02.021.

Rastogi, S., Pandey, M.M., and Rawat, A.K.S. (2016). Traditional herbs: A remedy for cardiovascular disorders. Phytomedicine 23(11): 10821089. doi:10.1016/j.phymed.2015.10.012.

Razayi, F., Mahmoudi, R., Rabiei, V., Aghdam, M.S., and Soleimani, A. (2018). Glycine betaine treatment attenuates chilling injury and maintains nutritional quality of hawthorn fruit during storage at low temperature. Sci. Hortic. 233: 188-194. doi:10.1016/j.scienta.2018.01.053.

Renda, G., Ozel, A., Barut, B., Korkmaz, B., and Yayli, N. (2018). In vitro protection by Crataegus microphylla extracts against oxidative damage and enzyme inhibition effects. Turk. J. Pharm. Sci. 15(1): 77-84.

Rezaei-Golmisheh, A., Malekinejad, H., Asri-Rezaei, S., Farshid, A.A., and Akbari, P. (2015). Hawthorn ethanolic extracts with triterpenoids and flavonoids exert hepatoprotective effects and suppress the hypercholesterolemia-induced oxidative stress in rats. Iranian J. Basic Med. Sci. 18(7): 691-699.

Rosa, S.I.G., Rios-Santos, F., Balogun, S.O., and Martins, D.T.D. (2016). Vitexin reduces neutrophil migration to inflammatory focus by down-regulating pro-inflammatory mediators via inhibition of $\mathrm{p} 38$, ERK1/2 and JNK pathway. Phytomedicine 23(1): 9-17. doi:10.1016/j. phymed.2015.11.003.

Saadatian, M., Najda, A., and Jasour, M.S. (2016). Drying process affects bioactive compounds in hawthorn species. Acta Sci. Pol. Hortoru. 15(4): 3-16.

Saeedi, G., Jeivad, F., Goharbari, M., Gheshlaghi, G.H., and Sabzevari, O. (2018). Ethanol extract of Crataegus oxyacantha L. ameliorate dietary non-alcoholic fatty liver disease in rat. Drug Res. 68(10): 553-
559. doi:10.1055/a-0579-7532.

Sarris, J. (2007). Herbal medicines in the treatment of psychiatric disorders: A systematic review. Phytother. Res. 21(8): 703-716. doi:10.1002/ ptr.2187.

Sayin, F.K., Altincam, M.H., and Kara, H.H. (2018). In vitro anti-diabetic activity of selected herbal teas extracted with different methods. $Z$. Arznei- Gewurzpfla. 23(2): 75-78.

Schini-Kerth, B., Ribeiro, T., Auger, C., Jabeen, Q., Da Silva, G.C., Medeiros, I.A., Boehm, N., and Monassier, L. (2015). Intake of a standardized crataegus extract prevents DOCA-salt-induced hypertension, and alteration of cardiac, vascular and renal structure and function in rats: role of oxidative stress. Eur. J. Heart Fail. 17: 368-369.

Schmitt, C.A., and Dirsch, V.M. (2009). Modulation of endothelial nitric oxide by plant-derived products. Nitric Oxide. 21(2): 77-91. doi:10.1016/j.niox.2009.05.006.

Shahidi, F. (2004). Functional foods: Their role in health promotion and disease prevention. J. Food Sci. 69(5): R146-R149.

Shahidi, F., and Yeo, J. (2018). Bioactivities of phenolics by focusing on suppression of chronic diseases: A review. Int. J. Mol. Sci. 19(6): 1573. doi:10.3390/ijms19061573.

Shao, F., Gu, L.F., Chen, H.J., Liu, R.H., Huang, H.L., and Ren, G. (2016). Comparation of hypolipidemic and antioxidant effects of aqueous and ethanol extracts of Crataegus pinnatifida fruit in high-fat emulsion-induced hyperlipidemia rats. Pharmacogn. Mag. 12(45): 64-69. doi:10.4103/0973-1296.176049.

Sixt, M., and Strube, J. (2018). Systematic design and evaluation of an extraction process for traditionally used herbal medicine on the example of hawthorn (Crataegus monogyna JACQ. Processes 6(7): 73. doi:10.3390/pr6070073.

Stelmakienè, A., Ramanauskienè, K., Petrikaitè, V., Jakštas, V., and Briedis, V. (2016). Application of dry hawthorn (Crataegus Oxyacantha L.) extract in natural topical formulations. Acta Pol. Pharm. 73(4): 955-965.

Trexler, S.E., Nguyen, E., Gromek, S.M., Balunas, M.J., and Baker, W.L. (2018). Electrocardiographic effects of hawthorn (Crataegus oxya cantha) in healthy volunteers: A randomized controlled trial. Phytother. Rese. 32(8): 1642-1646. doi:10.1002/ptr.6094.

Čulum, D., Čopra-Janićijević, A., Vidic, D., Klepo, L., Tahirović, A., Bašić, N., and Maksimović, M. (2018). HPLC-ED Analysis of phenolic compounds in three Bosnian Crataegus species. Foods 7(5): 66. doi:10.3390/foods7050066.

Veberic, R., Slatnar, A., Bizjak, J., Stampar, F., and Mikulic-Petkovsek, M. (2015). Anthocyanin composition of different wild and cultivated berry species. LWT Food Sci. Technol. 60(1): 509-517. doi:10.1016/j. Iwt.2014.08.033.

Veličković, J.M., Ilić, S., Mitić, S.S., Mitić, M.N., and Kostić, D.A. (2016). Comparative analysis of phenolic and mineral composition of hawthorn and blackthorn from southeast Serbia. Oxid. Commun. 39(3): 2280-2290.

Venskutonis, P.R. (2016). Hawthorn Juice. Handbook of Functional Beverages and Human Health In: Shahidi, F., and Alasalvar, C. (Ed.). CRC Press, 311-320.

Wang, Y.N., Zhen, Y.L., Wu, X., Jiang, Q., Li, X.L., Chen, Z.W., Zhang, G.L., and Dong, L.Y. (2015a). Vitexin protects brain against ischemia/ reperfusion injury via modulating mitogen-activated protein kinase and apoptosis signaling in mice. Phytomedicine 22(3): 379-384. doi:10.1016/j.phymed.2015.01.009.

Wang, X.S., Hu, X.C., Chen, G.L., Yuan, X., Yang, R.N., Liang, S., Ren, J., Sun, J.C., Kong, G.Q., Gao, S.G., and Feng, X.S. (2015b). Effects of Vitexin on the Pharmacokinetics and mRNA Expression of CYP Isozymes in Rats. Phytother. Res. 29(3): 366-372. doi:10.1002/ptr.5260.

Wang, X.R., Zhang, C.L., Peng, Y.J., Zhang, H.M., Wang, Z.G., Gao, Y., Liu, Y., and Zhang, H.L. (2018a). Chemical constituents, antioxidant and gastrointestinal transit accelerating activities of dried fruit of Crataegus dahurica. Food Chem. 246: 41-47. doi:10.1016/j.foodchem.2017.11.011.

Wang, X.W., Liang, Y., Shi, J., Zhu, H.J., and Bleske, B.E. (2018b). Crataegus special extract WS 1442 effects on eNOS and microRNA 155. Planta Med. 84(15): 1094-1100. doi:10.1055/a-0601-7083.

Wang, L.W., Yue, Z.W., Guo, M.Z., Fang, L.Y., Bai, L., Li, X.Y., Tao, Y.Q., Wang, S.Y., Liu, Q., Zhi, D.X., and Zhao, H. (2016). Dietary flavonoid hypero- 
side induces apoptosis of activated human LX-2 hepatic stellate cell by suppressing canonical NF-KB signaling. Biomed Res. Int. 2016 1068528.

Wen, L.R., Guo, X.B., Liu, R.H., You, L.J., Abbasi, A.M., and Fu, X. (2015) Phenolic contents and cellular antioxidant activity of Chinese hawthorn "Crataegus pinnatifida". Food Chem. 186: 54-62. doi:10.1016/j. foodchem.2015.03.017.

Wen, L.R., Guo, R.X., You, L.J., Abbasi, A.M., Li, T., Fu, X., and Liu, R.H. (2017). Major triterpenoids in Chinese hawthorn "Crataegus pinnatifida". and their effects on cell proliferation and apoptosis induction in MDA-MB-231 cancer cells. Food Chem. Toxicol. 100: 149-160.

Wen, L., Lin, Y.L., Lv, R.M., Yan, H.J., Yu, J.Q., Zhao, H.Q., Wang, X., and Wang, D.J. (2017b). An efficient method for the preparative isolation and purification of flavonoids from leaves of Crataegus pinnatifida by HSCCC and pre-HPLC. Molecules. 22(5): 767. doi:10.3390/molecules22050767.

Weon, J.B., Jung, Y.S., and Ma, C.J. (2016). Quality analysis of chlorogenic acid and hyperoside in Crataegi fructus. Pharmacogn. Mag. 12(46) 98-103. doi:10.4103/0973-1296.177904.

Wu, J.Q., Peng, W., Qin, R.X., and Zhou, H. (2014). Crataegus pinnatifida: Chemical constituents, pharmacology, and potential applications. Molecules. 19(2): 1685-1712. doi:10.3390/molecules19021685.

Wu, P.P., Li, F.J., Zhang, J.Y., Yang, B., Ji, Z.J., and Chen, W.D. (2017). Phytochemical compositions of extract from peel of hawthorn fruit, and its antioxidant capacity, cell growth inhibition, and acetylcholinesterase inhibitory activity. BMC Complement. Altern. Med. 17: 151. doi:10.1186/s12906-017-1662-y.

Wyspiańska, D., Kucharska, A.Z., Sokół-Łętowska, A., and Kolniak-Ostek, J. (2017). Physico-chemical, antioxidant, and anti-inflammatory properties and stability of hawthorn (Crataegus monogyna Jacq.) procyanidins microcapsules with inulin and maltodextrin. J. Sci. Food Agric. 97(2): 669-678. doi:10.1002/jsfa.7787.

Xia, N., Schramm, E., Koch, E., Burkart, M., Reifenberg, G., Forstermann, U., and Li, H. (2016). Crataegus extract WS (R) 1442 improves vascular function in diet-induced obese mice. Naunyn Schmiedebergs Arch. Pharmacol. 389(1): S38-S39.

Xie, W.D., Zhao, Y.A., and Du, L.J. (2012). Emerging approaches of traditional Chinese medicine formulas for the treatment of hyperlipidemia. J. Ethnopharmacol. 140(2): 345-367. doi:10.1016/j.jep.2012.01.027.
Yaglioglu, A.S., Eser, F., Tekin, S., and Onal, A. (2016). Antiproliferative ac tivities of several plant extracts from Turkey on rat brain tumor and human cervix carcinoma cell lines. Front. Life Sci. 9(1): 69-74. doi:10 $.1080 / 21553769.2015 .1089949$.

Yang, B.R., and Liu, P.Z. (2012). Composition and health effects of phenolic compounds in hawthorn (Crataegus spp.) of different origins. J. Sci. Food Agric. 92(8): 1578-1590. doi:10.1002/jsfa.5671.

Yonekubo, B.T., Alves, H.D.C., Marques, E.D., Perazzo, F.F., Rosa, P.C.P., Gaivao, I.O.D., and Maistro, E.L. (2018). The genotoxic effects of fruit extract of Crataegus oxyacantha (hawthorn) in mice. J. Toxicol. Environ. Health A 81(19): 974-982. doi:10.1080/15287394.2018.1503 982.

Yoo, J.H., Liu, Y., and Kim, H.S. (2016). Hawthorn fruit extract elevates expression of Nrf2/HO-1 and improves lipid profiles in ovariectomized rats. Nutrients 8(5): 283. doi:10.3390/nu8050283.

Zhang, F., Zhu, F.B., Li, J.J., Zhang, P.P., and Zhu, J.F. (2015). Hyperoside enhances the suppressive effects of arsenic trioxide on acute myeloid leukemia cells. Int. J. Clin. Exp. Med. 8(9): 15290-15295.

Zhao, B.L. (2005). Natural antioxidants for neurodegenerative diseases. Mol. Neurobiol. 31(1-3): 283-293.:31 1-3: 283.

Zheng, G.Q., Deng, J., Wen, L.R., You, L.J., Zhao, Z.G., and Zhou, L. (2018). Release of phenolic compounds and antioxidant capacity of Chinese hawthorn "Crataegus pinnatifida". during in vitro digestion. J. Funct. Foods. 40: 76-85.

Zhong, L., Wang, Y.W., Peng, W., Liu, Y.J., Wan, J., Yang, S.L., Li, L., Wu, C.J., and Zhou, X. (2015). Headspace Solid-Phase Microextraction coupled with Gas Chromatography-Mass Spectrometric analysis of volatile components of raw and stir-fried fruit of C-Pinnatifida (FCP). Trop. J. Pharm. Res. 14(5): 891-898. doi:10.4314/tjpr.v14i5.20.

Zhu, Q., Mao, L.N., Liu, C.P., Sun, Y.H., Jiang, B., Zhang, W., and Li, J.X (2016). Antinociceptive effects of vitexin in a mouse model of postoperative pain. Sci. Rep. 6: 19266. doi:10.1038/srep19266.

Zhu, Y., Feng, B., He, S.M., Su, Z.Q., and Zheng, G.J. (2018). Resveratrol combined with total flavones of hawthorn alleviate the endothelial cells injury after coronary bypass graft surgery. Phytomedicine 40: 20-26. doi:10.1016/j.phymed.2017.12.037.

Zorniak, M., Szydlo, B., and Krzeminski, T.F. (2017). Crataegus special extract WS 1442: Up-to-date review of experimental and clinical experiences. J. Physiol. Pharmacol. 68(4): 521-526. 